\title{
Ultrafine particle formation in the inland sea breeze airflow in Southwest Europe
}

\author{
R. Fernández-Camacho ${ }^{1}$, S. Rodríguez ${ }^{1,3}$, J. de la Rosa ${ }^{1}$, A. M. Sánchez de la Campa $^{2,1}$, M. Viana ${ }^{4}$, A. Alastuey ${ }^{4}$, and \\ X. Querol ${ }^{4}$ \\ ${ }^{1}$ University of Huelva, Joint Research Unit to CSIC “Atmospheric Pollution”, Campus El Carmen, E21071 Huelva, Spain \\ ${ }^{2}$ Estación Experimental del Zaidín, CSIC, C/Profesor Albareda 1, E18008 Granada, Spain \\ ${ }^{3}$ Izaña Atmospheric Research Centre, AEMET Joint Research Unit to CSIC "Studies on Atmospheric Pollution", La Marina \\ 20, planta 6, Santa Cruz de Tenerife, E38071, Canary Islands, Spain \\ ${ }^{4}$ Institute of Environmental Assessment and Water Research (IDÆA), CSIC, Jordi Girona, 18-26, 08034, Barcelona, Spain
}

Received: 12 May 2010 - Published in Atmos. Chem. Phys. Discuss.: 23 July 2010

Revised: 30 September 2010 - Accepted: 4 October 2010 - Published: 11 October 2010

\begin{abstract}
Studies on ultrafine particles (diameter $<100 \mathrm{~nm}$ ) and air quality have mostly focused on vehicle exhaust emissions and on new particle formation in "clean" ambient air. Here we present a study focused on the processes contributing to ultrafine particle concentrations in a city (Huelva, SW Spain) placed close to a coastal area where significant anthropogenic emissions of aerosol precursors occur. The overall data analysis shows that two processes predominantly contribute to the number of particles coarser than $2.5 \mathrm{~nm}$ : vehicle exhaust emissions and new particle formation due to photo-chemical activity. As typically occurs in urban areas, vehicle exhaust emissions result in high concentrations of black carbon (BC) and particles coarser than $2.5 \mathrm{~nm}(\mathrm{~N})$ during the morning rush hours. The highest $\mathrm{N}$ concentrations were recorded during the 11:00-17:00 $\mathrm{h}$ period, under the sea breeze regime, when low $\mathrm{BC}$ concentrations were registered and photochemical activity resulted in high $\mathrm{O}_{3}$ levels and in new particle formation in the aerosol precursors' rich inland airflow. In this period, it is estimated that about $80 \%$ of the number of particles are linked to sulfur dioxide emissions. The contributions to $\mathrm{N}$ of "carbonaceous material and those compounds nucleating/condensing immediately after emission" and of the "new particle formation processes in air masses rich gaseous precursors (e.g. $\mathrm{SO}_{2}$ )" were estimated by means of a relatively novel method based on simultaneous measurements of $\mathrm{BC}$ and $\mathrm{N}$. A comparison with two recent studies suggests that the daily cycles of "new particle forma-
\end{abstract}

Correspondence to:

R. Fernández-Camacho

(rocio.fernandez@dgeo.uhu.es) tion" during the inland sea breeze is blowing period seem to be a feature of ultrafine particles in coastal areas of Southwest Europe.

\section{Introduction}

Urban air quality impairment by atmospheric nano-sized particles is becoming a topic of great interest in the atmospheric and environmental sciences. A growing volume of scientific evidences shows that exposure to ultrafine particles (diameter $<100 \mathrm{~nm}$ ) results in harmful effects on human health (Araujo and Nel, 2009). Because deposition in the respiratory system of inhaled ultrafine particles is governed by diffusional processes, it is believed that ultrafine particle translocation within the human body is dependent on particle size, in such a way that the smallest ultrafine particles (e.g. $<5 \mathrm{~nm}$ ) mostly deposit in the nasopharyngeal region, whereas larger ultrafine particles ( $\geq 20 \mathrm{~nm}$ ) mostly reach the alveoli and enter the bloodstream (ICRP, 1994; Oberdörster et al., 2004). Many medical studies are currently focusing on translocation and the effects of solid ultrafine particles (rather than on liquid or semi-volatile aerosols). In a study with rats, Oberdörster et al. (2004) demonstrated that inhaled solid ultrafine particles deposited on the olfactory mucosa reach the central nervous system via the olfactory nerve. Translocation of inhaled ultrafine particles from the lungs to the liver and accumulation in the liver has been documented as occurring in a matter of a few hours (Oberdörster et al., 2002). Recent laboratory studies have elucidated the mechanism by which exposure to ultrafine particles enhances atherosclerosis and

Published by Copernicus Publications on behalf of the European Geosciences Union. 
cardiovascular ischemic events (Araujo et al., 2008). This may account for the association between "ambient particulate matter pollution" and "increased morbidity and mortality due to cardiovascular diseases" observed in epidemiological studies (Analitis et al., 2006). Chemical composition is also relevant; some ultrafine particles are constituted by potentially carcinogenic compounds (such as PAHs linked to soot; Morawska and Zhang, 2002). Given that these adverse effects on human health and because ultrafine particles are not properly quantified in terms of $\mathrm{PM}_{10}$ and $\mathrm{PM}_{2.5}$ (the current metrics in air quality standards), there is open debate on the necessity to regulate concentrations of ultrafine particles in ambient air (Second Position Paper on PM, 2004; COST 633 Report, 2009).

Ultrafine particles typically account for $80-90 \%$ of the total particle number concentration in urban air (Wehner and Wiedensohler, 2003; Rodríguez et al., 2007; Mejía et al., 2008). For this reason, many studies on ultrafine particles in urban air have been based on measurements of total number concentrations of particles coarser than $10 \mathrm{~nm}$ (e.g. Harrison and Jones, 2005) or $3 \mathrm{~nm}$ (e.g. Shi et al., 1999). Most studies attribute two main origins to these urban particles (e.g. Dunn et al., 2004; Morawska et al., 2008):

- Primary vehicle exhaust emissions. These particles show bimodal size distribution, with a nucleation $(<30 \mathrm{~nm})$ and a soot mode $(50-100 \mathrm{~nm})$. In general, it is believed that binary $\mathrm{H}_{2} \mathrm{O}-\mathrm{H}_{2} \mathrm{SO}_{4}$ nucleation and subsequent particle growth by condensation of sulphate and/or hydrocarbons during the dilution and cooling of the exhaust emissions plays an important role in the nucleation mode (Burtscher, 2005; Arnold et al., 2006). It has also been proposed that the formation mechanism may change depending on the exhaust after-treatment system, fuel composition, lubricant oil and environmental parameters (De Filippo and Maricq, 2008; Rönkkö et al., 2007; Du and Yu, 2008; Heikkilä et al., 2009). A fraction of the nucleation mode material is semi-volatile and its formation rate depends on the dilution conditions and on the temperature and relative humidity of the ambient air (Casati et al., 2007). The soot mode is made up of elemental carbon, absorbed organic material and some other trace elements formed in the engine and directly emitted in the solid phase (Burtscher, 2005; Rose et al., 2006).

- New particle formation in ambient air. This process is generally linked to nucleation and subsequent cluster/particle growth by condensation of photo-oxidized vapors (Morawska et al., 2008; Dunn et al., 2004). The cluster activation theory proposes that new particle formation occurs in two (not necessarily coupled) steps (Kulmala and Kerminen, 2008): i) nucleation of an initial cluster (the nucleation process itself), and ii) activation of these clusters resulting in particle growth to a detectable diameter. It has been observed that the clusters necessary for the initial steps seem to be always present in the atmosphere (Kulmala et al., 2005) and that nucleation of sulfuric acid gas molecules plays a key role in the formation of such stable clusters $(0.5-$ $1.5 \mathrm{~nm}$ size; Kulmala et al., 2006). Thus, the so-called new particle formation would occur when these clusters are activated and grow to detectable sizes. Sipilä et al. (2010) detected formation of $1.5 \mathrm{~nm}$ particles at atmospherically relevant sulfuric acid concentrations. It is believed that species involved in the nucleation step might not necessarily be the same as those involved in cluster/particle growth by condensation, and that nucleation (of clusters) and growth could be decoupled steps (Kulmala and Kerminen, 2008).

Our knowledge of ultrafine particles and urban air quality has experienced a significant increase in the last decade. However, some issues require more in-depth investigation. Some examples:

- Most studies have focused on vehicle exhaust emissions and on new particle formation in "clean" ambient air (e.g. references above). However, the contribution of other types of emission sources, such as plumes of particle precursors (e.g. industrial, ships, etc.), to ultrafine particle concentrations in ambient air has not been investigated in depth, even though it is well known that these activities may release important gaseous precursors. For example, Stanier et al. (2004) observed that nucleation was associated with the presence of $\mathrm{SO}_{2}$ and with radiation intensity.

- The influence of meteorology and the dispersion conditions of such aerosol precursor plumes on ultrafine particle formation in ambient air requires more in-depth investigation. In contrast, ultrafine particle formation during the cooling of vehicle exhaust emissions and their dilution and transport from a canyon street to the urban background has been widely studied (e.g. Wehner et al., 2002). Previous studies have shown that the development of coastal breezes in Southern Europe exerts a strong influence on the formation of ozone and secondary particles on a regional level (Millán et al., 2002; Rodríguez et al., 2004); however the influence of this meteorological scenario on the formation of ultrafine particles is unknown.

- There is a lack of techniques/methodologies for quantifying the sources and processes contributing to ultrafine particle concentrations in urban ambient air. A few attempts have been made. By applying receptor modeling techniques to a database of daily average values of $\mathrm{PM}_{2.5}$ chemical composition and particle size distribution, Pey et al. (2009) concluded that "vehicle exhaust emissions" and "new particle formation in ambient air" 
accounted for $65 \%$ and $24 \%$ of the $10-100 \mathrm{~nm}$ particles, respectively, in Barcelona. By using 10-min average data of black carbon and number of particles concentrations, Rodríguez and Cuevas (2007) estimated that ultrafine particles in Santa Cruz de Tenerife city mostly came from vehicle exhaust emissions during the morning rush hours, whereas about $70 \%$ of these ultrafine particles were linked to new particle formation in ambient air during the afternoon.

In this paper we present a study of ultrafine particles and industrial emissions of gaseous precursors. The objective is to identify the sources and processes contributing to ultrafine particle concentrations in ambient air downwind of coastal industrial emissions. The results show that these emissions coupled with suitable meteorological conditions typical of coastal areas give rise to high concentrations of ultrafine particles. These results show that "non-vehicle exhaust emission" sources may also contribute significantly to ultrafine particles in urban ambient air.

\section{Methodology}

\subsection{Study area}

The city of Huelva (around 140000 inhabitants) is located in the south-western part of the autonomous region of Andalusia in Spain (Fig. 1). The city spreads out over a flat area in the southern end of the "V"-shaped confluence between the Odiel and Tinto rivers. The city is surrounded by a ring road that allows road-traffic to connect the city with motorways (Fig. 1).

In addition to the typical urban vehicle exhaust emissions, aerosol precursors are emitted at the south of the city. These emissions are related to industrial activities (in Punta del Sebo and Nuevo Puerto industrial areas; Fig. 1) and to maritime transport (ship). According to the European Pollution Emission Register (EPER; http://eper.ec.europa.eu/ eper/) and to previous field studies (Querol et al., 2002; Alastuey et al., 2006; Sánchez de la Campa et al., 2007, 2008, 2009; Sánchez-Rodas et al., 2008; De la Rosa et al., 2010; Fernández-Camacho et al., 2010), the most significant industrial activities in Punta del Sebo include: i) a Cusmelter plant whose $\mathrm{SO}_{2}, \mathrm{H}_{2} \mathrm{SO}_{4}, \mathrm{As}, \mathrm{Sb}, \mathrm{Pb}, \mathrm{Zn}$ and $\mathrm{Sn}$ emissions are well documented, and ii) phosphoric acid production plants, which are a source of atmospheric $\mathrm{NH}_{4}^{+}$and Na phosphate, phosphoric acid, sulfuric acid and sodium silicate. Special attention is paid to the $\mathrm{Cu}$-smelter plant, given that it is a very significant source of $\mathrm{SO}_{2}$ and heavy metals (Fernández-Camacho et al., 2010). According to the above information sources, the most significant air pollutant emissions in Nuevo Puerto occur in a crude oil refinery resulting in emissions of volatile hydrocarbons, $\mathrm{SO}_{2}, \mathrm{NO}_{\mathrm{x}}, \mathrm{NH}_{3}, \mathrm{Ni}$, $\mathrm{V}$ and particulate matter. Finally, ship emissions may occur

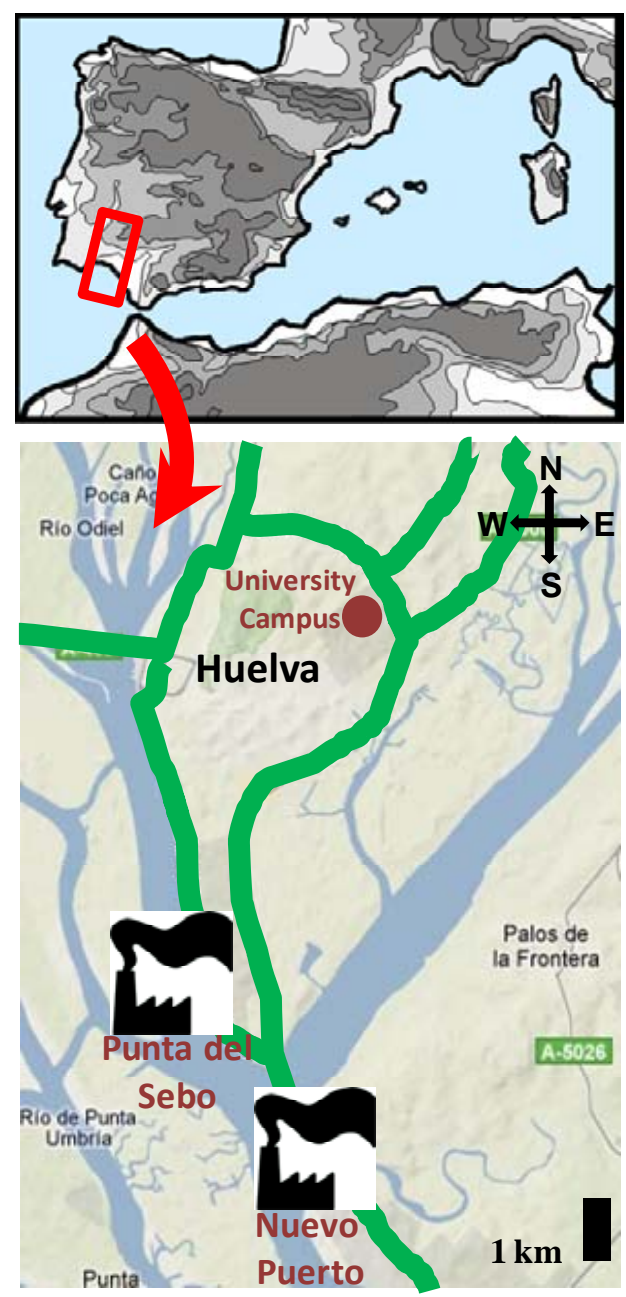

Fig. 1. Map of Huelva and the surroundings. Green lines indicate main roads and motorways around Huelva city. The two industrial areas (Punta del Sebo and Nuevo Puerto) of Huelva are highlighted.

in the harbor and in the bay of Huelva. This is a transit region for ships sailing to/from the Strait of Gibraltar, which $\sim 80000$ ships pass through every year (Viana et al., 2009). In all these cases sea-to-land winds result in the inland transport of aerosols and their precursors (e.g. $\mathrm{SO}_{2}$ ).

The dispersion and transport of air pollutants in this area are highly influenced by the topographic setting (Mantilla, 2007). At night, the wind mostly blows from the north, associated with the channeling of airflows along the Guadalquivir basin, prompted by the synoptic Azores anticyclone. During daylight, southern airflows linked to thermally driven breezes predominate. In this period, the inland entry of coastal breeze coupled with the airflow channeled along the river pathway, favor the entry of industrial plumes from the Punta del Sebo and Nuevo Puerto areas to the city centre. This sea breeze blowing inland is typically associated with an increase in ozone concentrations (Millán et al., 2002). 


\subsection{Measurements}

Data on particle number, black carbon and $\mathrm{PM}_{10}$ concentrations, gaseous pollutant concentrations $\left(\mathrm{NO}_{\mathrm{x}}, \mathrm{SO}_{2}\right.$ and $\mathrm{O}_{3}$, among others) and meteorological parameters were collected at the urban background air pollution research station located at the University Campus. This site is situated on the northeast side of the city, $7 \mathrm{~km}$ from Punta del Sebo and $14 \mathrm{~km}$ from Nuevo Puerto industrial areas. The closest roads, Avenida Andalucia and Avenida Fuerzas Armadas lie about 500 and $1000 \mathrm{~m}$ to the west and the east of the measurement site, respectively (Fig. 1). The current study is based on data collected between April 2008 and September 2009. Data availability in this period is of about $70 \%$ for particle number, $95 \%$ for black carbon, $80 \%$ for $\mathrm{PM}_{10}, 85 \%$ for $\mathrm{NO}_{\mathrm{x}}, 85 \%$ for $\mathrm{SO}_{2}, 87 \%$ for $\mathrm{O}_{3}$ and $100 \%$ for radiation, wind speed, wind direction, temperature and relative humidity.

\subsubsection{Particles}

Number concentration of particles was monitored using an Ultrafine Condensation Particle Counter (UCPC, TSI ${ }^{\mathrm{TM}}$ ), model 3776. According to the manufacturer, this instrument detects particles coarser than $2.5 \mathrm{~nm}$. Experimental measurements performed by Hermann et al. (2007) have shown that the $50 \%$ counting efficiency for these instruments is reached at diameters $\left(d_{50}\right)$ between 3 and $4 \mathrm{~nm}$. The CPC unit used in this study (SN 70530189) was inter-compared with other unit (SN 70601252) of the same model at the begging of the campaign. Results show a high linearity between the two instruments and that the differences were of about $0.2 \%$ for 10 min averaged data (Fig. 2a).

The instrument records data averaged at 1-min intervals. It was operated in high flow mode $(1.5 \mathrm{l} / \mathrm{m})$ to minimize diffusion losses. $\mathrm{N}$ is considered representative of the ultrafine particle concentration. This is supported by previous studies that showed that the number of particles with size 10$100 \mathrm{~nm}$ typically accounts for $80-90 \%$ of the total number concentrations in urban air (Wehner and Wiedensohler, 2003; Rodríguez et al., 2007).

Concentrations of black carbon particles (BC) smaller than $10 \mu \mathrm{m}$ were monitored by placing a $\mathrm{PM}_{10}$ impactor in the inlet of a Multi-Angle Absorption Photometer (MAAP) (Thermo ${ }^{\mathrm{TM}}$, model Carusso 5012). BC concentrations were determined using the absorption coefficient measurements at $\lambda=630 \mathrm{~nm}\left(\sigma_{\mathrm{ap}}\right.$ in $\mathrm{Mm}^{-1}$ units) taken with the MAAP by applying Eq. (1) (Petzold and Schönlinner, 2004):

$\mathrm{BC}\left(\mu \mathrm{g} \mathrm{m}^{-3}\right)=\sigma_{\mathrm{ap}}\left(\mathrm{Mm}^{-1}\right) / \sigma\left(\mathrm{m}^{2} \mathrm{~g}^{-1}\right)$

where $\sigma$ is the "specific aerosol absorption coefficient" (expressed in $\mathrm{m}^{2} / \mathrm{g}$ units). In order to determine " $\sigma$ ", samples of $\mathrm{PM}_{10}$ particles were collected in a high volume $\left(68 \mathrm{~m}^{3} / \mathrm{h}\right)$ sampler. In these $\mathrm{PM}_{10}$ samples, elemental carbon (EC) concentrations were determined by analysis in the laboratory. These were performed by means of the Thermo Op-
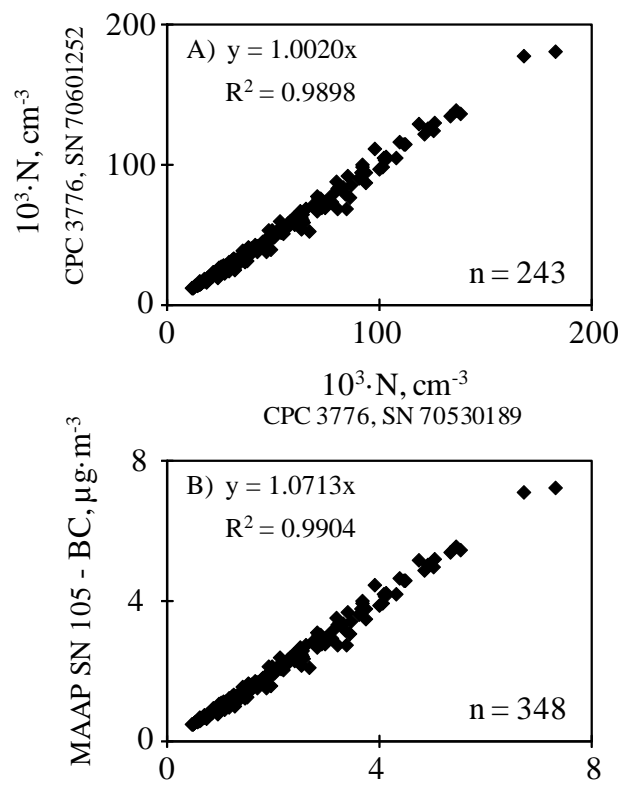

MAAP SN $100-\mathrm{BC}, \mu g \cdot \mathrm{m}^{-3}$

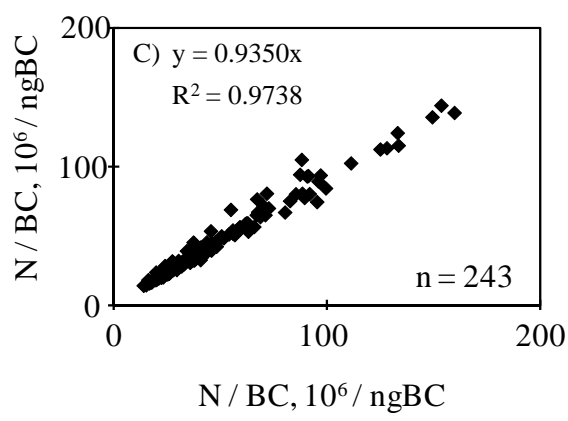

Fig. 2. Inter-comparison between the 10 min averaged data recorded with two CPCs model 3776, two MAAPs and the N/BC ratio recorded with these instruments. Data plotted in Y-axis were collected with the instruments (CPC SN70530189, MAAP SN 105) used in this study.

tical Transmittance technique (Birch and Cary, 1996) using a Sunset Laboratory ${ }^{\mathrm{TM}}$ OC-EC analyzer and the default temperature steps of the EUSAAR2 program. A parallel $\mathrm{PM}_{2.5}$ sampling was occasionally performed to determine the $\mathrm{PM}_{2.5} / \mathrm{PM}_{10}$ ratio for BC. The MAAP used in this study (SN 105) was also inter-compared with other MAAP instrument at the beginning of the campaign (Fig. 2b). The N/BC ratios measured with these instruments were also inter-compared (Fig. 2c).

Concentrations of $\mathrm{PM}_{10}$ particles were determined by means of a beta attenuation monitor and a sampler for collecting $\mathrm{PM}_{10}$ samples on filter media. Daily average gravimetric $\mathrm{PM}_{10}$ concentrations were determined by filter weighing after conditioning $\left(20^{\circ} \mathrm{C}\right.$ and $\left.50 \% \mathrm{RH}\right)$. Gravimetric equivalent hourly average $\mathrm{PM}_{10}$ concentrations were determined by multiplying the $\mathrm{PM}_{10}$ readings of the beta monitor 

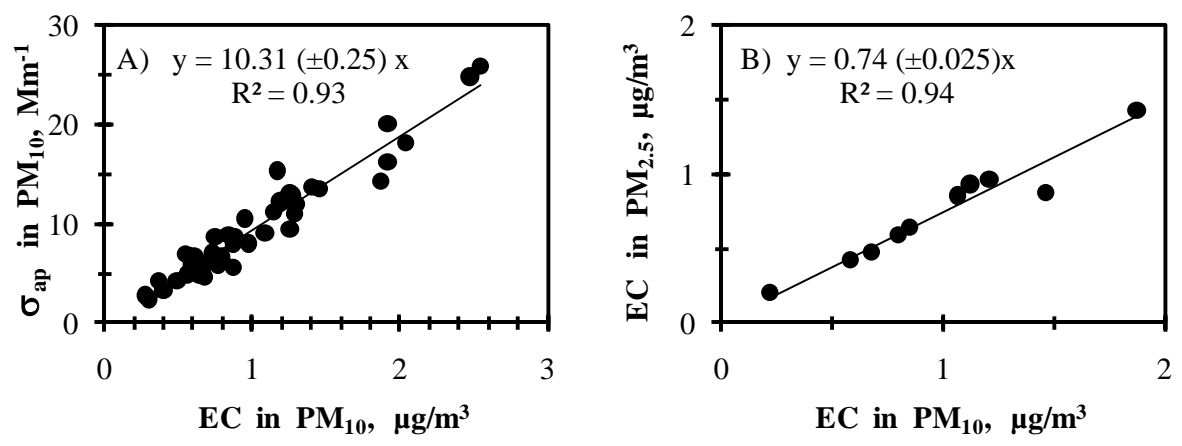

Fig. 3. (A) absorption coefficient $\sigma_{\text {ap }}$ versus EC concentrations in $\mathrm{PM}_{10}$ particles, (B) $\mathrm{BC}$ in $\mathrm{PM}_{10}$ versus $\mathrm{BC} \mathrm{PM}_{2.5}$.

by the "correction factor" required to take into account losses due to volatilization in the beta instrument. This was done by following the EU standardized procedure (EC Working Group on Particulate Matter Report, 2002).

\subsubsection{Additional data}

The following complementary measurements were performed: i) concentrations of $\mathrm{SO}_{2}, \mathrm{NO}_{\mathrm{x}}$ and $\mathrm{O}_{3}$ were monitored using standard procedures following the reference methods of the European air quality directives (2008/50/EC), ii) road-traffic intensity (number of vehicles $\cdot$ hour $^{-1}$ ) was measured on the two main roads at each side of the measurement site, iii) meteorological parameters (wind speed and direction, temperature, relative humidity, pressure and global radiation).

\section{Results and discussion}

\subsection{Absorbing aerosols}

The specific aerosol absorption coefficient $\sigma$ (expressed in $\mathrm{m}^{2} / \mathrm{g}$ units) was determined by comparing the absorption coefficient $\sigma_{\text {ap }}$ measured by the MAAP with the elemental carbon (EC) concentrations determined by the Sunset analysis of the $\mathrm{PM}_{10}$ samples. An average value of $\sigma=$ $10.31 \pm 0.25 \mathrm{~m}^{2} / \mathrm{g}$ was obtained (Fig. 3a). This $\sigma$ value is within the range of those typically observed in previous studies $\left(2-25 \mathrm{~m}^{2} \mathrm{~g}^{-1}\right.$; Bond and Bergstrom, 2006). Because of the low $\sigma$ values typically associated with other potentially absorbing species, such as mineral dust $\left(0.01-0.02 \mathrm{~m}^{2} \mathrm{~g}^{-1}\right.$; Alfaro et al., 2004) or organic aerosols (e.g. humic-like substances $\sigma \sim 0.03 \mathrm{~m}^{2} \mathrm{~g}^{-1}$; Hoffer et al., 2006), and because of the high correlation observed between absorption coefficient and nitrogen oxides during the morning rush hours (Fig. 4b, discussed below), we assume that the measured absorption coefficient is entirely due to absorption by EC. Observe in Fig. $3 \mathrm{~b}$ that about the $75 \%$ of the EC mass in $\mathrm{PM}_{10}$ occurs in the fine $\left(\mathrm{PM}_{2.5}\right)$ fraction.

\subsection{Regular daily evolution}

Figure 4 shows the hourly average values for particle number $\mathrm{N}$ and black carbon $\mathrm{BC}$ concentrations, several gaseous pollutants $\left(\mathrm{NO}_{\mathrm{x}}\right.$ and $\left.\mathrm{SO}_{2}\right)$ and the road-traffic intensity for each day of the week. The high correlation between $\mathrm{BC}, \mathrm{NO}_{\mathrm{x}}$ and "road-traffic intensity/wind speed" ratio (all of them showing high values during the morning rush hours of working days) indicates that a predominant fraction of these pollutants is linked to vehicle exhaust emissions. This is also evidenced in the working-days-to-weekend change in the $\mathrm{BC}$ and $\mathrm{NO}_{\mathrm{x}}$ daily evolution. The daily evolution of $\mathrm{N}$ is somewhat different to that of $\mathrm{BC}$. The abrupt morning increase in road-traffic intensity and in $\mathrm{N}$ evidence the significant influence of vehicle exhaust emissions on the ultrafine particle concentrations in this period. In contrast, the decrease observed in the "road-traffic intensity/wind speed" ratio and in $\mathrm{BC}$ and $\mathrm{NO}_{\mathrm{x}}$ concentrations after the morning rush hours (Fig. $4 \mathrm{~b}$ and c) is not observed in N. This suggests that other sources (not linked to $\mathrm{BC}$ and $\mathrm{NO}_{\mathrm{x}}$ emissions) and/or processes are actively contributing to $\mathrm{N}$ during the central hours of daylight. The correlation between the daily evolution of the N/BC ratio, $\mathrm{SO}_{2}$ and solar radiation suggests that this additional mechanism providing ultrafine particles during the noon-afternoon period may be related to new particle formation in the $\mathrm{SO}_{2}$ downwind of the industrial plumes that reach the measurement area during the period when the sea breeze is blowing inland (Fig. 4d).

Most of studies on ultrafine particles in urban air have been based on measurements of particles $>10 \mathrm{~nm}$. In European cities, these particles typically exhibit mean concentrations within the range $15000-30000 \mathrm{~cm}^{-3}$ (Ruuskanen et al., 2001; Van Dingenen et al., 2004; Puustinen et al. 2007; Rodríguez et al., 2007; Putaud et al., 2010). Putaud et al. (2010) observed a clear increase in particle number when moving from rural background to urban background and kerbsides; moreover, no differences in the rural background throughout Europe were observed. 

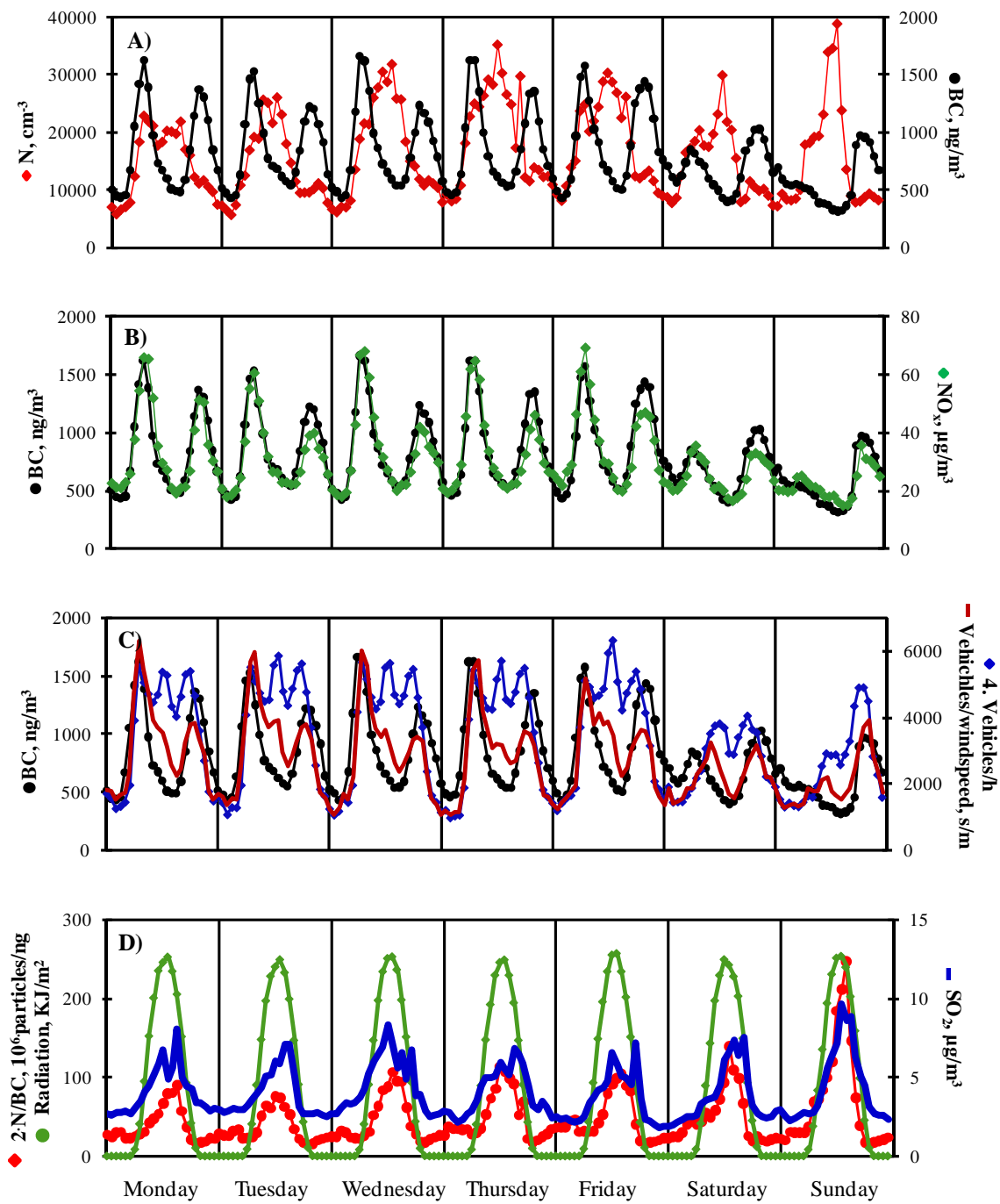

Fig. 4. Hourly average values of particles $(\mathrm{N}$ and $\mathrm{BC})$ and gaseous pollutant $\left(\mathrm{NO}_{\mathrm{x}}\right.$ and $\left.\mathrm{SO}_{2}\right)$ concentrations, and of road-traffic intensity (number of vehicles/hour), the road-traffic intensity/wind speed ratio, of the N/BC ratio and solar radiation, for every day of the week.

We have made an effort to compare mean concentrations of $>2.5 \mathrm{~nm}$ particles in Huelva with those recorded in other cities; however data on these types of particles are still scarce. The mean value of the $\geq 2.5 \mathrm{~nm}$ particle number concentrations recorded in Huelva is $\left(\sim 22000 \mathrm{~cm}^{-3}\right)$ within the range of those typically recorded in other urban background sites $\left(\sim 20000 \mathrm{~cm}^{-3}\right.$ in Santa Cruz de Tenerife city and $\sim 22000 \mathrm{~cm}^{-3}$ in Pittsburg for $\sim 3 \mathrm{~nm}$ particles; Rodríguez and Cuevas, 2007; Stanier et al., 2004) and much lower than those recorded in street canyons and road-traffic sites $\left(\sim 64000 \mathrm{~cm}^{-3}\right.$ in Leipzig and $170000 \mathrm{~cm}^{-3}$ in Birmingham for $\geq 3 \mathrm{~nm}$ particles; Wehner et al., 2002; Shi et al., 1999). One of the most important features of the $\geq 2.5 \mathrm{~nm}$ particles in Huelva is their regular daily evolution. In most urban areas, the number of $\geq 3 \mathrm{~nm}$ particles reaches a maximum mostly during the morning rush hours (e.g. Leipzig, Santa Cruz de Tenerife) due to vehicle exhaust emissions. In contrast, the maximum concentrations of $\geq 2.5 \mathrm{~nm}$ particles in Huelva are reached during the afternoon (12:00-14:00 $\mathrm{h}$ ).

\subsection{Relationship between particle number and black carbon concentrations}

Correlations between particle number and black carbon concentrations are regularly observed in urban air due to vehicle exhaust emissions (Fruin et al., 2004; Rodríguez et al., 2007; Rodríguez and Cuevas, 2007). These correlations are also observed in Huelva.

We have analyzed the relationship between the particle number $\mathrm{N}$ and black carbon $\mathrm{BC}$ concentrations following the methodology described by Rodríguez and Cuevas (2007). Figure 5 shows the $\mathrm{N}$ versus $\mathrm{BC}$ scatter plots for different periods of the day (00:00-05:00 h, 06:00-09:00 h, 10:0015:00 $\mathrm{h}$ and 18:00-23:00 h). It can be observed that at any 

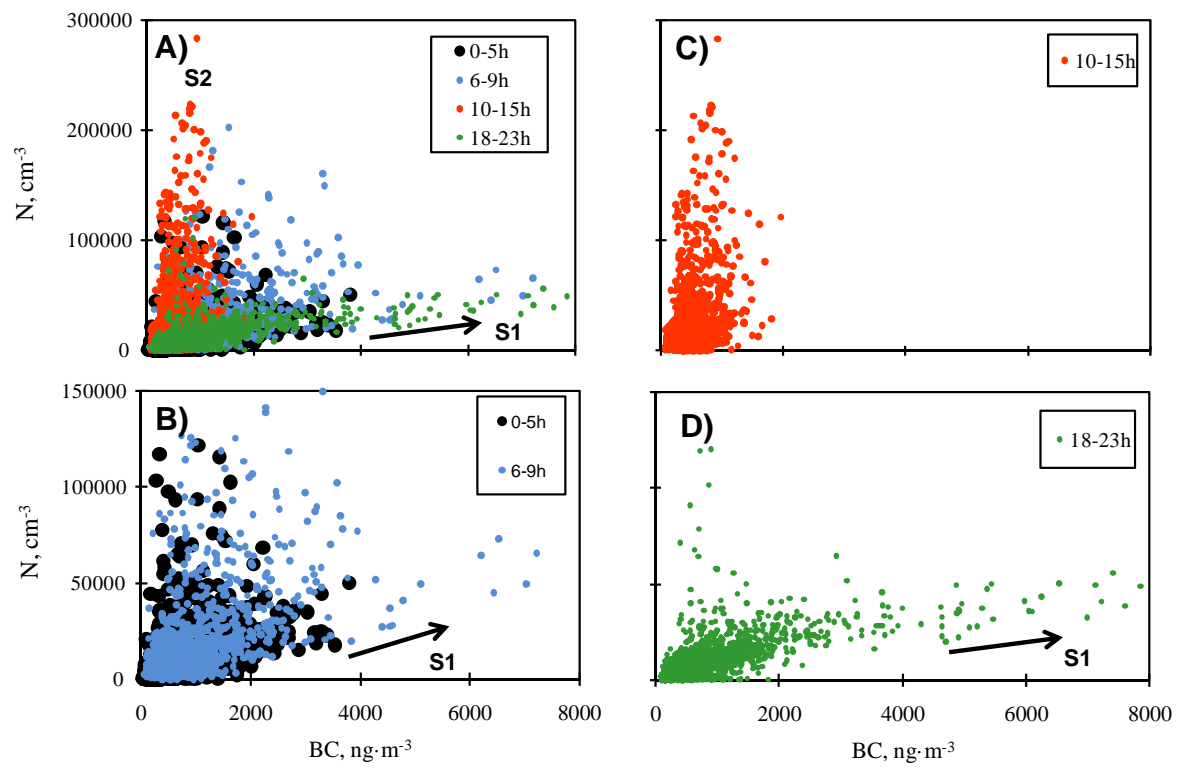

Fig. 5. Hourly average values of the particle number N versus BC particle concentrations at different times of the day in Huelva city. S1 and $\mathrm{S} 2$ indicate the lines of minimum and maximum slopes which contain the N-vs.-BC data.

period, the $\mathrm{N}$ versus $\mathrm{BC}$ data set is grouped between two well defined borders with slopes $\mathrm{S} 1$ and $\mathrm{S} 2$, representing the minimum and maximum N/BC ratios, respectively (Fig. 5a). Table 1 shows the values of slopes $\mathrm{S} 1$ and $\mathrm{S} 2$ obtained in different periods of the day. During the $\mathrm{NO}_{\mathrm{x}}$ morning peak period (06:00-09:00 h), S1 showed a value of $6.9 \times 10^{6}$ particles per nanogram of black carbon (particles/ng BC) and it is interpreted as the minimum number of particles formed/emitted per each nanogram of $\mathrm{BC}$ emitted by vehicle exhausts. In this period, S2 showed a value of $148 \times 10^{6}$ particles/ng BC. Increases in the $\mathrm{N} / \mathrm{BC}$ ratio, from $\mathrm{S} 1=6.9 \times 10^{6}$ particles/ng BC up to $S 2=148 \times 10^{6}$ particles/ng $B C$ as maximum value, are interpreted to be caused by enhancements in the new particle formation processes during the dilution and cooling of the vehicle exhaust emissions and/or in ambient air (Casati et al., 2007; Gidhagen et al., 2005). During the evening $\mathrm{NO}_{\mathrm{x}}$ peak period (18:00-23:00 h), S1 and S2 show values close to those observed during the morning $\mathrm{NO}_{\mathrm{x}}$ peak hours (Table 1). From mid-morning to the afternoon period (10:00-15:00 h), $\mathrm{S} 1$ showed a value of $66 \times 10^{6}$ particles/ngBC, which is an order of magnitude higher than that observed during the morning rush hours. This much higher number of particles per each nanogram of $\mathrm{BC}$ in the ambient air is attributed to the activation of an additional new particle formation mechanism (not linked to primary BC emissions). This is supported by the fact that the $\mathrm{S} 1$ slope is not as well defined during the 10:00-15:00 $\mathrm{h}$ period as during the morning $\mathrm{NO}_{\mathrm{x}}$ peak period (06:00-09:00 h). This high N/BC ratio and the low correlation between $\mathrm{N}$ and $\mathrm{BC}$ are caused by new particle formation processes not linked to vehicle exhaust emissions.
Table 1. Values of the slopes $S 1$ and $S 2$ obtained with the methodology described by Rodríguez and Cuevas (2007). S1 and S2 are expressed as $10^{6}$ particles/ng BC.

\begin{tabular}{lrrr}
\hline Period & & $\mathrm{S} 1$ & $\mathrm{~S} 2$ \\
\hline Daily & $00: 00-23: 00 \mathrm{~h}$ & 4.70 & 356.60 \\
Night & $00: 00-05: 00 \mathrm{~h}$ & 6.78 & 350.60 \\
Morning & $06: 00-09: 00 \mathrm{~h}$ & 6.90 & 148.40 \\
Mid morning to afternoon & $11: 00-17: 00 \mathrm{~h}$ & 66.30 & 356.60 \\
Evening & $18: 00-23: 00 \mathrm{~h}$ & 4.70 & 23.16 \\
\hline
\end{tabular}

The $\mathrm{S} 1$ value found during the morning $\mathrm{NO}_{\mathrm{x}}$ peak in Huelva city $\left(6.9 \times 10^{6}\right.$ particles $(>2.5 \mathrm{~nm}) / \mathrm{ng}$ BC) is close to those observed in other cities: $4.94 \times 10^{6}$ particles $(>3 \mathrm{~nm}) / \mathrm{ng}$ BC in Santa Cruz de Tenerife, $4.69 \times 10^{6}$ particles $(>10 \mathrm{~nm}) / \mathrm{ng}$ BC in Barcelona and $4.75 \times 10^{6}$ particles $(>10 \mathrm{~nm}) / \mathrm{ng}$ BC in Milan (Rodríguez and Cuevas, 2007). In Huelva the S2 slope is much higher than that observed in other cities, for example $\mathrm{S} 2$ in the mid-morning to afternoon period is equal to $4710^{6}$ particles/ng BC in Santa Cruz de Tenerife and $356 \times 10^{6}$ particles/ng BC in Huelva. This indicates "high new particle formation" activity in Huelva from mid-morning to afternoon. In fact, the N/BC ratios in Huelva $\left(50-150 \times 10^{6}\right.$ particles/ng BC; Fig. 4d) are much higher than those observed in other cities such as Santa Cruz de Tenerife and Barcelona (15-25 $\times 10^{6}$ particles/ng BC; Rodríguez et al., 2008; Pérez et al., 2010). 

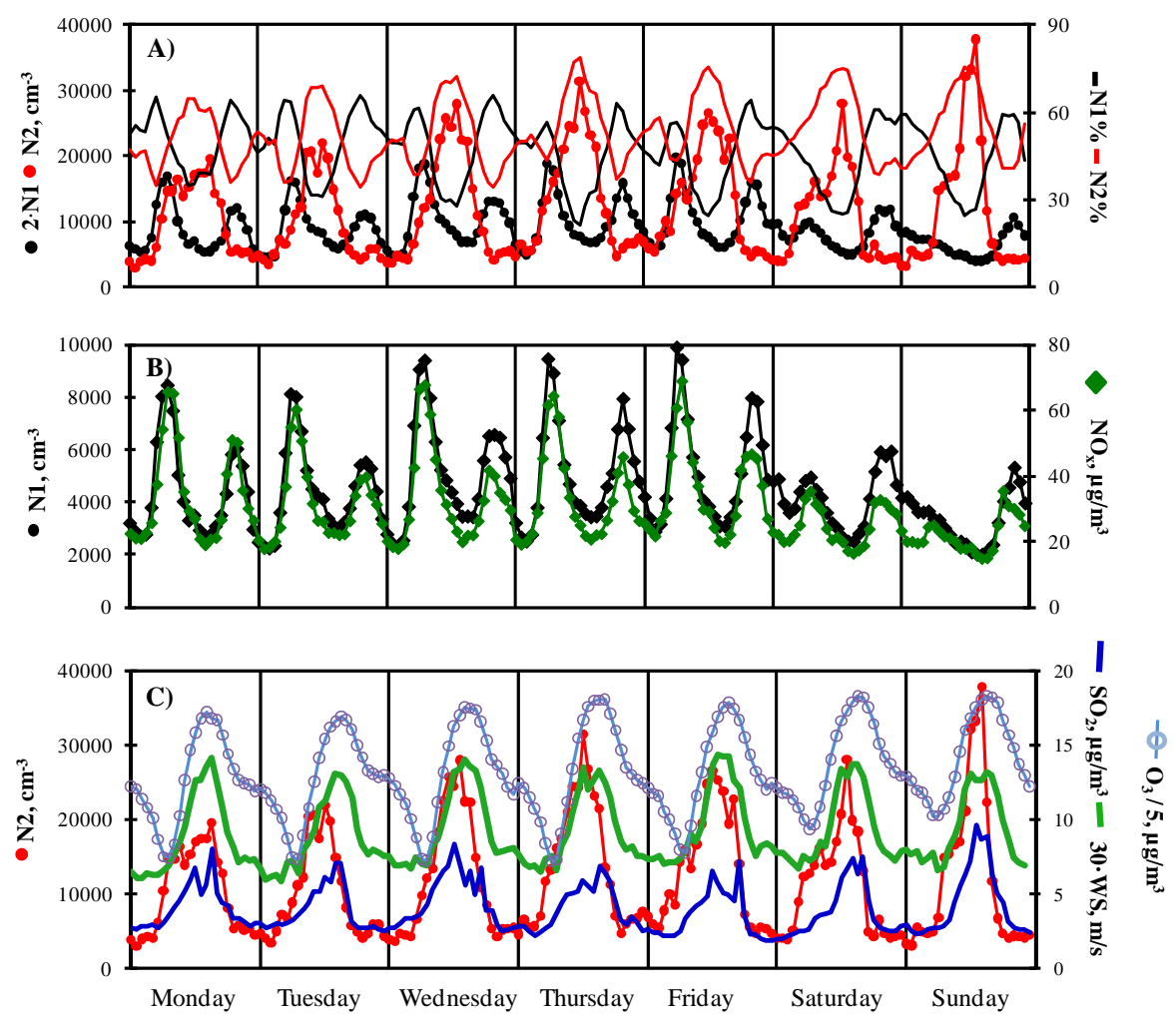

Fig. 6. Hourly average values of $\mathrm{N} 1$ and $\mathrm{N} 2$ particles (expressed in terms of absolute $\mathrm{cm}^{-3}$ and relative contributions) and gaseous pollutant $\left(\mathrm{NO}_{\mathrm{x}}, \mathrm{SO}_{2}\right.$ and $\left.\mathrm{O}_{3}\right)$ concentrations and of wind speed for every day of the week.

\subsection{Sources of ultrafine particles}

\subsubsection{Components of ultrafine particles}

In order to identify the sources and processes affecting ultrafine particle concentration, $\mathrm{N}$ was split in two components following the methodology of Rodríguez and Cuevas (2007):

$\mathrm{N} 1=\mathrm{S} 1 \cdot \mathrm{BC}$

$\mathrm{N} 2=\mathrm{N}-\mathrm{N} 1$

where, according to the results shown in the previous section, a value of $\mathrm{S} 1=6.9 \times 10^{6}$ particles/ng BC (the $\mathrm{N}$-vs.-BC slope during the morning $\mathrm{NO}_{\mathrm{x}}$ ) was chosen. Rodríguez and Cuevas interpreted $\mathrm{N} 1$ as representative of "those components directly emitted in the particle phase" and "those compounds nucleating immediately after the vehicle exhaust emission" (because they are in the aerosol phase under regular ambient air conditions). Thus, N1 accounts for incomplete fuel combustion products (e.g. black carbon, long-chain organic matter compounds or PAH), condensed trace metals, unburned oil and a fraction of sulphate and organic compounds nucleating/condensing immediately after emission (as described by Kittelson, 1998; Burtscher, 2005; Arnold et al., 2006; Rose et al., 2006). The component $\mathrm{N} 2$ is related to those processes giving rise to the aforementioned increases in the N/BC ratio, i.e. enhancement in the new particle formation rates due to increased nucleation and/or growth rates to detectable sizes ( $\geq 2.5 \mathrm{~nm}$ in our case). Rodríguez and Cuevas (2007) reasoned that this enhancement in the new particle formation rates may occur in different contexts, such as "during the dilution and cooling of the vehicle exhaust emissions" (e.g. as described by Charron and Harrison, 2003; Casati et al., 2007) or in ambient air due to photochemistry (e.g. as described by Woo et al., 2001; Wehner et al., 2002). Thus, all primary particles due to vehicle exhaust are included in N1, all nucleation particles not linked to vehicle exhaust emission are included in $\mathrm{N} 2$, and nucleation particles formed immediately after dilution of the vehicle exhaust may contribute to both $\mathrm{N} 1$ and N2. Thus, this is a very useful method that provides an estimation of the fraction of the total number concentration that is linked to the "carbonaceous solid phase" emitted by vehicle exhausts (although N1 may include a fraction of compounds nucleating immediately after emission) and of the fraction linked to "nucleation mode particles". The latter may be related to gaseous precursors emitted by different sources and should be studied site-to-site (industrial, ships, biogenic, etc.). Figure 6 shows the hourly average values of $\mathrm{N} 1$ and $\mathrm{N} 2$ for every day of the week; these results will be discussed below. 


\subsubsection{Identification of sources}

In order to identify the sources and processes affecting particle number $\mathrm{N}$ concentration, a set of Principal Component Analyses (PCA) followed by varimax rotations were performed using 1-h average data. Because the principal components (PC) obtained depend on the number and types of variables introduced in the PCA, a number of tests were performed. Initially, only particles $\left(\mathrm{N} 1, \mathrm{~N} 2\right.$ and $\left.\mathrm{PM}_{10}\right)$ and primary gaseous pollutants $\left(\mathrm{NO}_{\mathrm{x}}\right.$ and $\left.\mathrm{SO}_{2}\right)$ were introduced. In a second step, different combinations of meteorological parameters, "road-traffic intensity/wind speed" ratio and ozone were chosen. Moreover, PCA were performed separately with the data collected during the morning rush hours (06:00-09:00 $\mathrm{h}$ ) and during the noon-afternoon period (11:00-17:00 h). Winter and summer periods were also segregated. Thus, about 40 PCAs were performed. For the sake of brevity, only four examples are shown (Table 2). Correlations between meteorological parameters and PC including particle number concentrations were observed only in some cases. The following PCs were persistently observed:

- a principal component (PC-1) positively correlated with $\mathrm{N} 1, \mathrm{NO}_{\mathrm{x}}, \mathrm{PM}_{10}$ and the "road-traffic intensity/wind speed" ratio was observed in the morning both in winter and in summer. This profile supports the interpretation of the N1 origin described above: mostly carbonaceous material directly emitted in the particle phase and compounds nucleating/condensing immediately after the emission (Rose et al., 2006). Thus, this PC represents a fraction of the particles emitted by vehicle exhausts (mostly the solid phase). Observe in Fig. $8 \mathrm{~b}$ and $f$ that $\mathrm{N} 1$ and $\mathrm{NO}_{\mathrm{x}}$ reach their highest concentrations during the morning and evening rush hours. These exhaust emissions and road-dust resuspension account for the $\mathrm{PM}_{10}$ association in this PC. Association with temperature and/or relative humidity was not observed due to the primary nature of these N1 particles. This PC was also observed in the noon-afternoon of the winter period, but not in the summer probably because of the enhanced dilution conditions in the warm season.

- PC-2 in the morning was positively correlated with N2 and $\mathrm{SO}_{2}$. This association supports the interpretation of the $\mathrm{N} 2$ origin described above: new particle formation by nucleation and particle growth to a detectable size ( $\geq 2.5 \mathrm{~nm}$; Arnold et al., 2006). These $\mathrm{SO}_{2}$ emissions in the morning (when this pollutant typically shows relatively low concentrations, $3-10 \mu \mathrm{g} / \mathrm{m}^{3}$ ) are attributed to vehicle exhaust emissions (light and heavy duty engines). The fact that high $\mathrm{N} 2$ and $\mathrm{SO}_{2}$ concentrations are observed when the wind blows from the north (as in the case of $\mathrm{N} 1$ and $\mathrm{NO}_{\mathrm{x}}$; Fig. 7A1 and 7B1) and the positive correlation of $U$ and $V$ wind components in this factor, indicates the influence of exhaust emissions from vehicles running along the northern side of
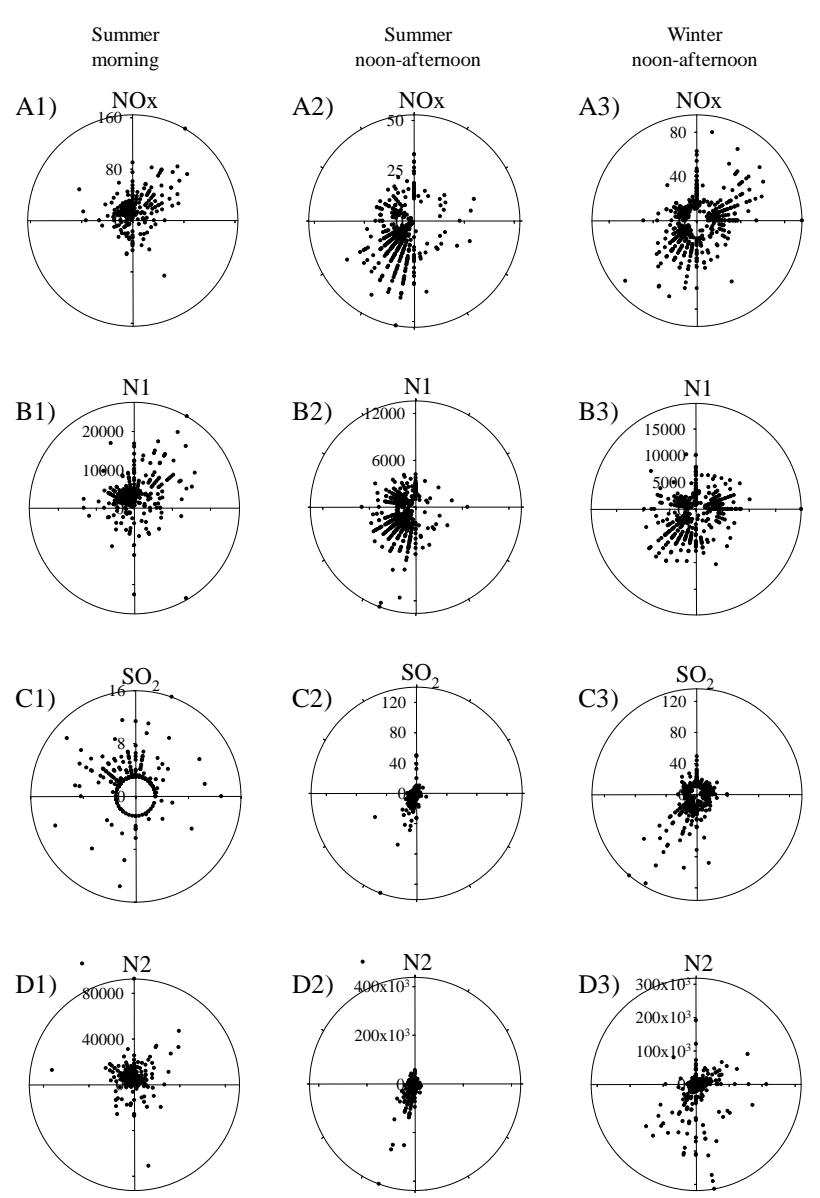

Fig. 7. Hourly mean values of $\mathrm{N} 1$ and $\mathrm{N} 2$ particles and of $\mathrm{NO}_{\mathrm{x}}$ and $\mathrm{SO}_{2}$ concentrations during the summer morning (06:00-09:00 h), summer noon-afternoon and winter noonafternoon (11:00-17:00 $\mathrm{h}$ ) as functions of wind direction.

the ring road around Huelva city (Fig. 1 and Fig. 7C1 and 7D1). Observe in Fig. 8c that the N2 maximum in the morning is only observed in winter. The fact that solar radiation is also correlated with this factor suggests that $\mathrm{SO}_{2}$ photo-oxidation during transport from the road (where the emission takes place) to our background measurement site may enhance new particle formation rates (Pirjola, 1999).

- PC-2 was also correlated with $\mathrm{N} 2$ and $\mathrm{SO}_{2}$ in the noonafternoon period. In this period, the northward inland breeze blowing favors the inland transport of the industrial $\mathrm{SO}_{2}$ plumes (emitted in the shore; Fig. 1) and the fumigations over the city. For this reason, the highest $\mathrm{SO}_{2}$ concentrations were recorded when the wind blew from the SSW $\left(\sim 185^{\circ}\right)$, where the $\mathrm{Cu}$-smelter and refinery plants are located (Fig. $7 \mathrm{C} 2$ and $\mathrm{C} 3$ ). The fact that concentrations of $\mathrm{SO}_{2}$ during the noon-afternoon were higher during winter than during summer is associated with the seasonal change in the sea breeze blowing. In 
Table 2. Factor loading of the Principal Components Analysis (followed by a varimax rotation) obtained with hourly data in the morning (06:00-09:00 h) and noon-afternoon (11:00-17:00 h) in summer (June-September 2008) and winter periods (January-March 2009). Factor loadings with absolute values $\geq 0.6$ are in bold. RAD: Solar radiation; VEHICLES/WS: Number of vehicles/hour; $U$ : zonal component of wind (west-east); $V$ : meridional component of wind (south-nort). \#NI: variable non included in this example.

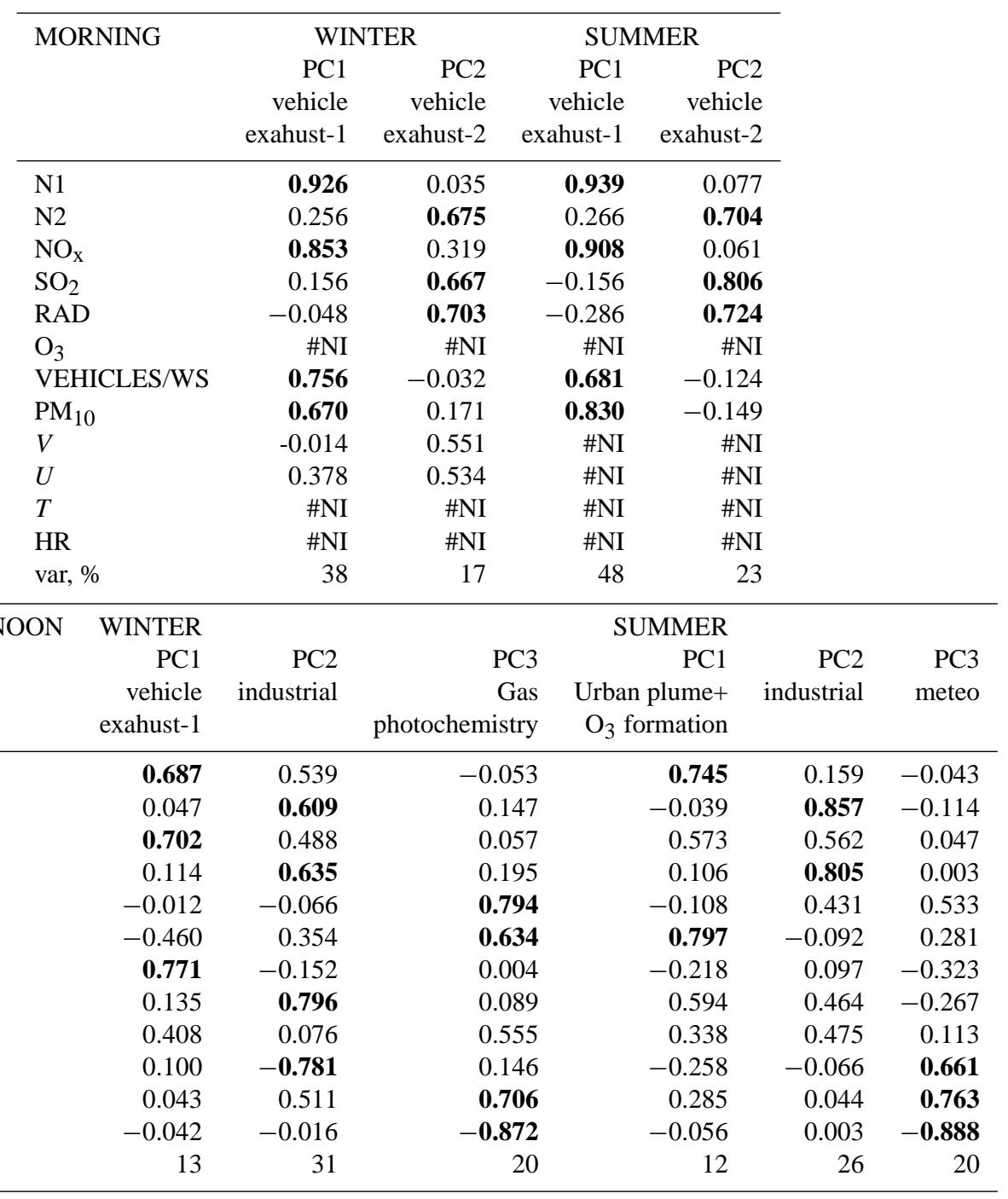

wintertime, the change in wind direction from NNE at night to $S$ during the afternoon occurred via the east (clockwise; Fig. 8a). This resulted in frequent fumigations of the plumes over the city and in high $\mathrm{SO}_{2}$ concentrations in the 11:00-17:00 h period (Fig. 8c). In summer, the night (NW) to afternoon (SW) change in wind direction occurred via the west (counterclockwise) and consequently the plumes were very frequently transported westward without impacting on the city. For this reason, the afternoon $\mathrm{SO}_{2}$ and $\mathrm{N} 2$ concentrations were lower in summer than in winter (Fig. $8 \mathrm{c}$ and $8 \mathrm{~g}$ ). This association between southern winds and $\mathrm{N} 2$ and $\mathrm{SO}_{2}$ is clearly observed in PC-2 in winter (Table 2),
- PC-3 represents relationships between meteorological parameters and $\mathrm{O}_{3}$.

In order to quantify the relationship between "N1 and N2" and " $\mathrm{NO}_{\mathrm{x}}$ and $\mathrm{SO}_{2}$ ", an analysis with data averaged in intervals of $25 \mu \mathrm{g} \mathrm{NO}_{\mathrm{x}} / \mathrm{m}^{3}(0-25,25-50, \ldots)$ and $1 \mu \mathrm{g} \mathrm{SO} \mathrm{S}_{2} / \mathrm{m}^{3}(0-$ $1,1-2, \ldots)$ was performed in order to reduce the other influencing parameters (Fig. 9). Observe that N1 showed high linearity with $\mathrm{NO}_{\mathrm{x}}$ (Fig. 9a and e) but not with $\mathrm{SO}_{2}$ (Fig. 9b and f). Similarly, $\mathrm{N} 2$ did not show correlation with $\mathrm{NO}_{\mathrm{x}}$ (Fig. 9c and g), but exhibited high linearity with $\mathrm{SO}_{2}$ (Fig. 9d and h). The fact that no correlation between $\mathrm{N} 2$ and $\mathrm{SO}_{2}$ is observed during the summer morning is attributed to the influence of temperature on the condensation processes that result 

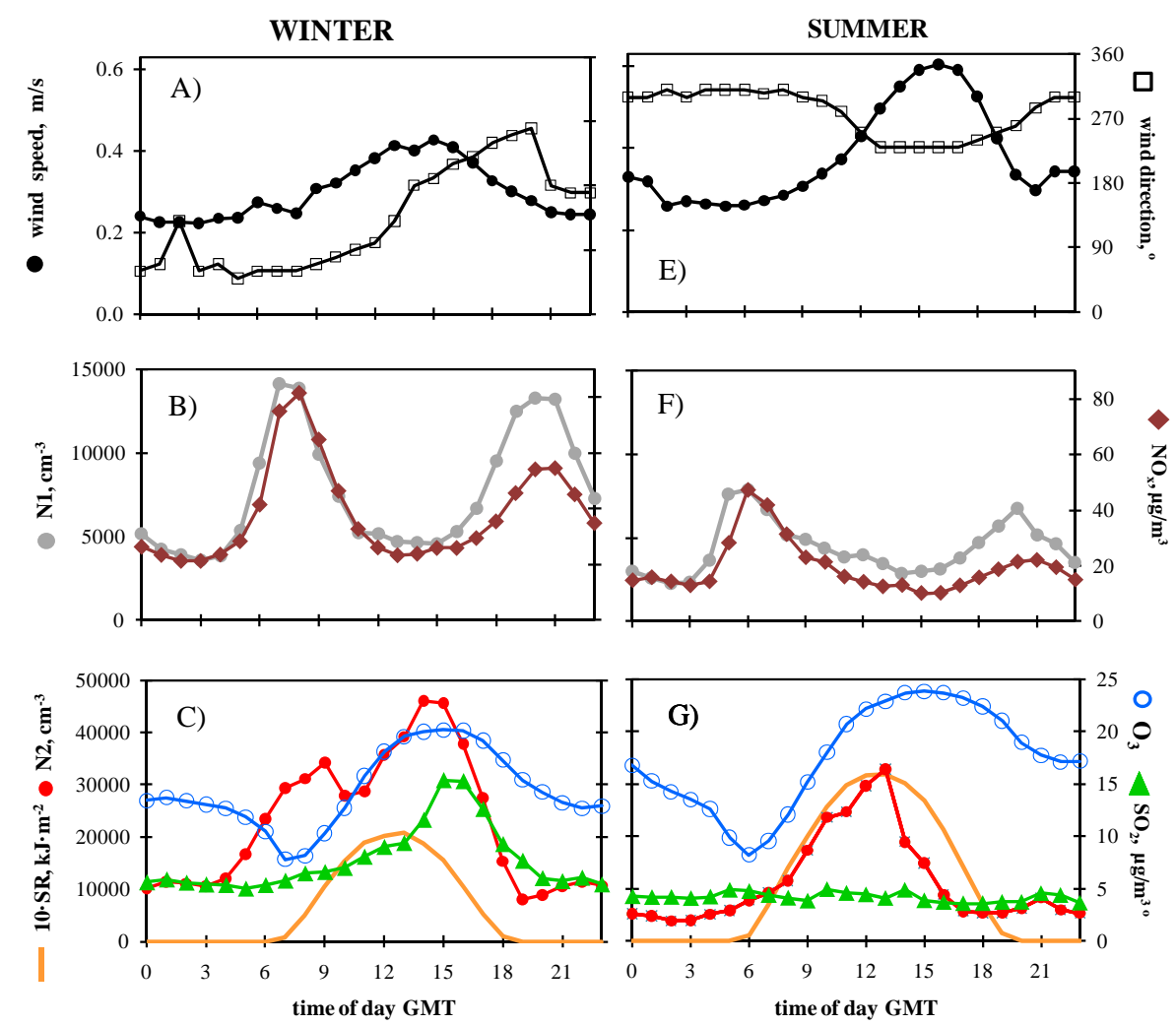

Fig. 8. Hourly average values of $\mathrm{N} 1, \mathrm{~N} 2, \mathrm{NO}_{\mathrm{x}}, \mathrm{SO}_{2}$ and $\mathrm{O}_{3}$ concentrations, of wind speed and direction and of solar radiation ( $\mathrm{SR}$ ) in $\mathrm{Huelva}$ in winter and summer.

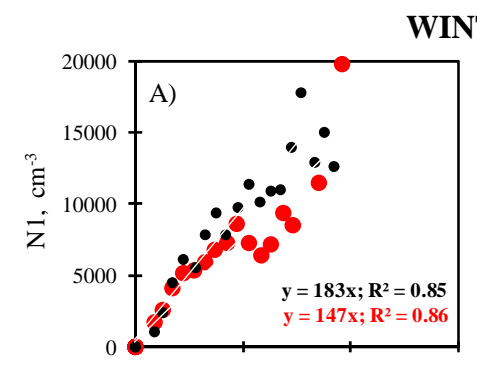

WINTER

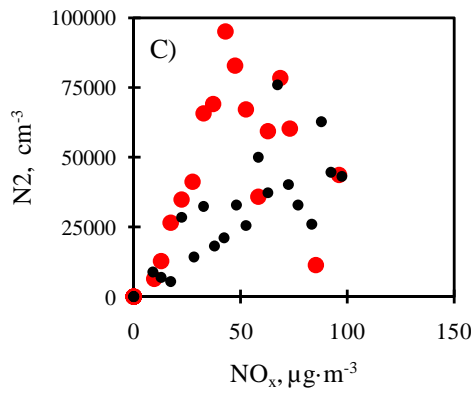

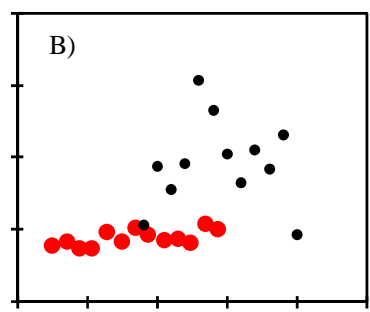

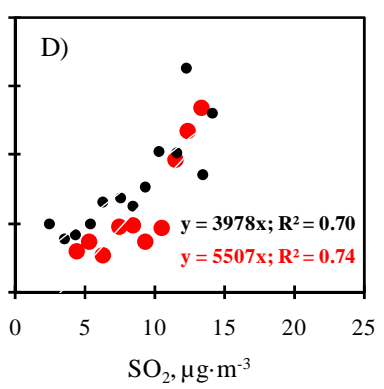

SUMMER
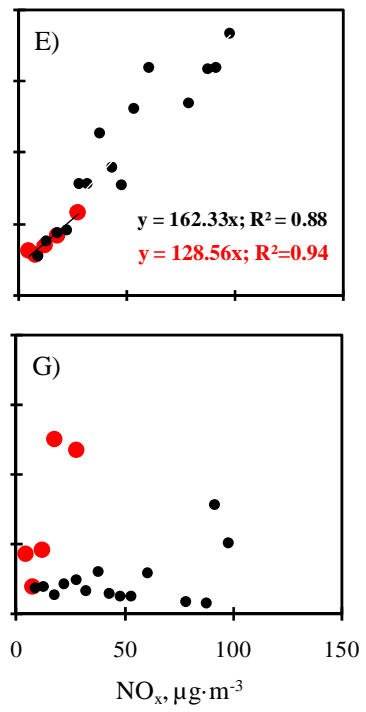

Fig. 9. Concentrations of $\mathrm{N} 1$ and $\mathrm{N} 2$ particles versus $\mathrm{NO}_{\mathrm{x}}$ and $\mathrm{SO}_{2}$ during the morning (black circles) and noon-afternoon (red circles) in winter and summer. Data are averaged in $25 \mu \mathrm{gNO} \mathrm{x}_{\mathrm{x}} / \mathrm{m}^{3}$ interval widths $(0-25,25-50, \ldots)$ and every $1 \mu \mathrm{gSO}_{2} / \mathrm{m}^{3}$ interval width $(0-1,1-2$, $2-3, \ldots)$. 
Table 3. Mean number concentrations and contributions of N1 and N2 in different periods during the whole study period, in winter and in summer.

\begin{tabular}{llrrrrr}
\hline & & $\begin{array}{r}\mathrm{N} \\
\mathrm{cm}^{-3}\end{array}$ & $\begin{array}{r}\mathrm{N} 1 \\
\mathrm{~cm}^{-3}\end{array}$ & $\begin{array}{r}\mathrm{N} 2 \\
\mathrm{~cm}^{-3}\end{array}$ & $\begin{array}{r}\mathrm{N} 1 \\
\%\end{array}$ & $\begin{array}{r}\mathrm{N} 2 \\
\%\end{array}$ \\
\hline Summer 2008 & & & & & & \\
\hline Night & $00: 00-05: 00 \mathrm{~h}$ & 8582 & 3660 & 4922 & 42 & 58 \\
Morning & $06: 00-09: 00 \mathrm{~h}$ & 16228 & 5248 & 10979 & 35 & 65 \\
Afternoon & $10: 00-15: 00 \mathrm{~h}$ & 34686 & 3299 & 31387 & 19 & 81 \\
Evening & $18: 00-23: 00 \mathrm{~h}$ & 11175 & 5203 & 5972 & 48 & 52 \\
All day & $00: 00-23: 00 \mathrm{~h}$ & 17185 & 4183 & 13002 & 36 & 64 \\
\hline Winter 2009 & & & & & & \\
\hline Night & $00: 00-05: 00 \mathrm{~h}$ & 15912 & 4915 & 10997 & 38 & 62 \\
Morning & $06: 00-09: 00 \mathrm{~h}$ & 38734 & 9906 & 28828 & 34 & 66 \\
Afternoon & $10: 00-15: 00 \mathrm{~h}$ & 40639 & 4722 & 35917 & 22 & 78 \\
Evening & $18: 00-23: 00 \mathrm{~h}$ & 20286 & 10303 & 9983 & 50 & 50 \\
All day & $00: 00-23: 00 \mathrm{~h}$ & 28979 & 7088 & 21504 & 36 & 64 \\
\hline Summer 2009 & & & & & & \\
\hline Night & $00: 00-05: 00 \mathrm{~h}$ & 11542 & 4890 & 6652 & 46 & 54 \\
Morning & $06: 00-09: 00 \mathrm{~h}$ & 26688 & 7262 & 19069 & 36 & 64 \\
Afternoon & $10: 00-15: 00 \mathrm{~h}$ & 41220 & 3634 & 36698 & 20 & 80 \\
Evening & $18: 00-23: 00 \mathrm{~h}$ & 11173 & 4950 & 6233 & 49 & 51 \\
All day & $00: 00-23: 00 \mathrm{~h}$ & 21558 & 4874 & 16263 & 38 & 62 \\
\hline & & & & & &
\end{tabular}

in cluster growth to detectable sizes, $\geq 2.5 \mathrm{~nm}$ (Gidhagen et al., 2005; Casati et al., 2007). This is supported by the fact that the $\mathrm{N} 2$ versus $\mathrm{SO}_{2}$ slope for the period 06:00-09:00 $\mathrm{h}$ showed a decreasing trend with temperature (slope $=3258$ for $T$ : $0.0-3.5^{\circ} \mathrm{C}, 2874$ for $T 3.5-4.5^{\circ} \mathrm{C}, 857$ for $T$ : $4.5-$ 5.5), and no correlation between $\mathrm{N} 2$ and $\mathrm{SO}_{2}$ was observed for temperatures $>6^{\circ} \mathrm{C}$. Observe that $\mathrm{N} 2$ showed a morning maximum (linked to vehicle exhaust emissions) in winter (Fig. 8c) but not in summer (Fig. 8g). The fact that the correlation between $\mathrm{N} 2$ and $\mathrm{SO}_{2}$ is observed from low to high $\mathrm{SO}_{2}$ concentrations, suggests that $\mathrm{N} 2$ is predominantly influenced by the $\mathrm{SO}_{2}$ plume dispersion scenarios (Fig. 9d and h). Similarly, N1 is dominated by vehicle exhaust products (Fig. 9a and 9e).

\subsection{Contributions to ultrafine particle concentrations}

Figure 6 shows the hourly average values of $\mathrm{N} 1, \mathrm{~N} 2, \mathrm{NO}_{\mathrm{x}}$, $\mathrm{SO}_{2}$ and $\mathrm{O}_{3}$ concentrations and of wind speed for every day of the week. Table 3 shows the average values of $\mathrm{N}$ and the contributions of $\mathrm{N} 1$ and $\mathrm{N} 2$. The highest $\mathrm{N} 1$ concentrations were recorded during the morning rush hours on working days, when ultrafine particles $(\mathrm{N})$ are mostly attributed to vehicle exhaust emissions. In this period, when $\mathrm{N}$ showed an average value of $\sim 27000 \mathrm{~cm}^{-3}$, the contributions of $\mathrm{N} 1$ and $\mathrm{N} 2$ accounted for $35 \%$ and $65 \%$ of $\mathrm{N}$, respectively.
The weekly evolution of N2 is significantly different to that of N1. High N2 concentrations are observed during the period when the sea breeze is blowing inland. Observe that the increase in $\mathrm{N} 2$ concentrations (from 11:00 h) is correlated with the increase in wind speed and in $\mathrm{SO}_{2}$ and $\mathrm{O}_{3}$ concentrations (Fig. 6c). The parallel between $\mathrm{N} 2$ and solar radiation suggests the active role of $\mathrm{SO}_{2}$ photo-oxidation in new particle formation during the inland transport of $\mathrm{SO}_{2}$ plumes (Fig. 8c and 8g). During this 11:00-17:00 h period, when $\mathrm{N}$ typically shows values of $\sim 39000 \mathrm{~cm}^{-3}$, N2 accounted for $80 \%$ of $\mathrm{N}$.

In order to quantify the contributions of $\mathrm{N} 1$ and $\mathrm{N} 2$ to $\mathrm{N}$, data were classified from the highest to lowest values of $\mathrm{N}$ (100th to 1st percentile). The contributions of N1 and N2 to $\mathrm{N}$ are highlighted in black and grey, respectively (Fig. 10a and e). It can clearly be observed that increasing $\mathrm{N}$ concentrations are associated with much higher increases in N2 than in N1 concentrations (Fig. 10a and d). Thus, during N2 events representing the 80th percentile, N1 only accounted for about $20 \%$ of $\mathrm{N}$ during the morning rush hours and for $10 \%$ of $\mathrm{N}$ during the 11:00-17:00 $\mathrm{h}$ period (Fig. 10b and e). The fact that ultrafine particles may reach higher concentrations during the 11:00-17:00 h period (up to $130000 \mathrm{~cm}^{-3}$ ) than during the morning (up to $90000 \mathrm{~cm}^{-3}$ ) is prompted by the much higher contributions of N2. Figure 10c and $\mathrm{f}$ show the $\mathrm{SO}_{2}$ concentrations associated with each $\mathrm{N}$ value plotted in Fig. 10a and d. These results evidence the important 

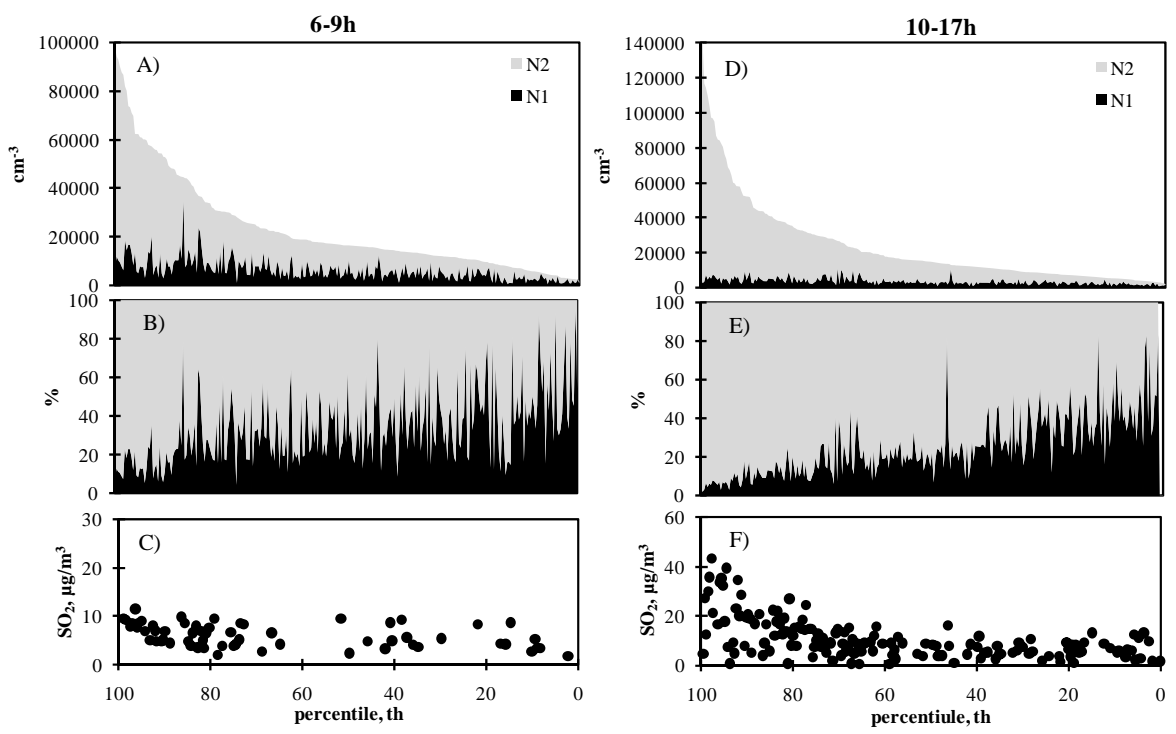

Fig. 10. Hourly average values of total number concentration $(\mathrm{N}=\mathrm{N} 1+\mathrm{N} 2)$ classified from the highest (100th) to the lowest (0th) value. The contributions of N1 (black) and N2 (grey) to N, in absolute $\left(\mathrm{cm}^{-3} ; \mathbf{A}\right.$ and $\left.\mathbf{D}\right)$ and relative $(\% ; \mathbf{B}$ and $\mathbf{E})$ concentrations, are highlighted. The $\mathrm{SO}_{2}$ concentrations associated with the decreasing $\mathrm{N}$ values (from 100th to 0 th) are plotted ( $\mathbf{C}$ and $\mathbf{F}$ ).

involvement of the $\mathrm{SO}_{2}$ emissions in the ultrafine particle pollution several (7-14) kilometers downwind. Observe in Fig. 10c and $\mathrm{f}$ that increasing $\mathrm{N}$ values from the 1st to 100th percentile are associated with increasing $\mathrm{SO}_{2}$ concentrations from 10 to $20 \mu \mathrm{g} / \mathrm{m}^{3}$ in the morning and from about 5 to $50 \mu \mathrm{g} / \mathrm{m}^{3}$ in the 11:00-17:00 h period. This increasing trend with ultrafine particles was not observed in $\mathrm{NO}_{\mathrm{x}}$ (not shown).

\section{Summary and conclusions}

Most studies on ultrafine particles and air quality have focused on vehicle exhaust emissions and on new particle formation in ambient air mostly under "clean air" conditions. In this article we have presented a study of the processes influencing ultrafine particle concentrations in an urban coastal area where significant emissions of gaseous particle precursors take place (Huelva, SW Spain). These emissions are mostly linked to industrial activities. The study is based on measurements of the number of particles coarser than $2.5 \mathrm{~nm}$ $(\mathrm{N})$, particulate black carbon (BC), gaseous pollutants and meteorological parameters taken over 17 months in an urban background site located $7-14 \mathrm{~km}$ from the industrial area.

By using the minimum slope observed in the $\mathrm{N}$ versus BC plot $\left(6.9 \times 10^{6}\right.$ particles/ng BC), $\mathrm{N}$ was split into two components: $\mathrm{N}=\mathrm{N} 1+\mathrm{N} 2$. Component $\mathrm{N} 1$ shows high values during the morning and evening rush hours on working days, and it is highly correlated with the "road-traffic intensity/wind speed" ratio. This component (N1) correlates with $\mathrm{NO}_{\mathrm{x}}$, the light-absorption coefficient due to carbonaceous material and elemental carbon determined by analysis on filter. In contrast, it does not correlate with $\mathrm{SO}_{2}$. N1 accounts for vehicle exhaust emissions of carbonaceous material and may also include compounds nucleating/condensing immediately after emission. Component $\mathrm{N} 2$ shows a behavior well differentiated from that of N1. It is correlated with $\mathrm{SO}_{2}$ and accounts for new particle formation due to nucleation and rapid particle growth to detectable sizes $(\geq 2.5 \mathrm{~nm})$. Every day, the highest $\mathrm{N} 2$ concentrations were recorded during the 11:00-17:00 $\mathrm{h}$ period, when the sea breeze blowing inland resulted in simultaneous increases in wind speed and in the concentrations of $\mathrm{N} 2, \mathrm{SO}_{2}$ and $\mathrm{O}_{3}$. This behavior is attributed to new particle formation in the inland sea breeze airflow due to photo-oxidation of gaseous aerosol precursors and the subsequent nucleation/condensation of oxidized vapors, with $\mathrm{SO}_{2}$ being a key component. In wintertime, an additional secondary $\mathrm{N} 2$ maximum was observed during the morning rush hours, with this being attributed to vehicle exhaust emissions containing sulfur compounds. During the morning rush hours, when ultrafine particles are attributed to vehicle exhaust emissions and about $27000 \mathrm{~cm}^{-3}$ are typically observed, the contribution of $\mathrm{N} 1$ and $\mathrm{N} 2$ accounted for $35 \%$ and $65 \%$ of $\mathrm{N}$, respectively. In the 11:00-17:00 $\mathrm{h}$ period, when about $39000 \mathrm{~cm}^{-3}$ are typically observed, the contribution of $\mathrm{N} 2$ accounted for $80 \%$ of $\mathrm{N}$, with these (N2) particles being attributed to new particle formation in sulfurrich air masses. These results evidence how industrial $\mathrm{SO}_{2}$ emissions may result in ultrafine particle pollution several kilometers downwind of the emission source. Moreover, the contributions of these emissions are frequently much higher than those from vehicle exhausts. 
The daily cycles of "new particle formation" during the period when the sea breeze is blowing inland described here, have recently been observed in other coastal cities located in the southern part of the European Union, such as Santa Cruz de Tenerife and Barcelona (Rodríguez et al., 2008; Pérez et al., 2010). The overall observations suggest that new particle formation seems to be favored in the inland sea breeze airflow. Moreover, new particle formation rates are enhanced under high emission rates of gaseous aerosol precursors in the shore (ships, power plants and/or industrial states). The fact that the N/BC ratios in Huelva during the period when the sea breeze is blowing inland (N/BC: $50-125 \times 10^{6}$ particles/ng BC) are much higher than those observed in Santa Cruz de Tenerife and Barcelona (N/BC: $15-25 \times 10^{6}$ particles/ng BC in both cities) is attributed to the much higher emission rates of aerosol precursors in this highly industrialized region. These observations contrast with those made in Central - Northern Europe, where ultrafine particles in urban air are mostly attributed to vehicle exhaust emissions, with new particle formation in urban air being observed during some summer periods (e.g. Wehner and Wiedensohler, 2003).

Finally, it is also interesting to highlight that the method used here to segregate the particle number into components, $\mathrm{N} 1$ and N2, allows accounting for particles linked to vehicle exhaust emissions and particles originated from other sources and/or processes. This offers a great potential for forthcoming source apportionment studies and for air quality assessment for human health protection.

Acknowledgements. This study has been carried out within the framework of several research projects: AER-REG (P07-RNM03125; Department of Innovation, Science and Enterprise of the Andalusian Autonomous Government), GRACCIE (CSD200700067; Ministry of Science and Innovation of Spain), SIMAND (P07- RNM-02729; Department of Innovation, Science and Enterprise of the Andalusian Autonomous Government) and EPAU (B026/2007/3-10.1; Ministry of Environment of Spain). We would like to thank to the Council of Huelva for providing the road-traffic intensity data.

Edited by: V.-M. Kerminen

\section{References}

Alastuey, A., Querol, X., Plana, F., Viana, M., Ruiz, C. R., Sánchez de la Campa, A. M., de la Rosa, J., Mantilla, E., and García dos Santos, S.: Identification and chemical characterisation of industrial PM sources in SW Spain, J. Air Waste Manage., 56, 993-1006, 2006.

Alfaro, S. C., Lafon, S., Rajot, J. L., Formenti, P., Gaudichet, A., and Maille, M.: Iron oxides and light absorption by pure desert dust: An experimental study, J. Geophys. Res.-Atmos., 109(8), D08208, doi:10.1029/2003JD004374, 2004.

Analitis, A., Katsouyanni, K., Dimakopoulou, K., Samoli, E., Nikoloulopoulos, A.K., Petasakis, Y., Touloumi, G., Schwartz,
J., Anderson, H. R., Cambra, K., et al.: Short-term effects of ambient particles on cardiovascular and respiratory mortality, Epidemiology, 17(2), 230-233, 2006.

Araujo, J. A., Barajas, B., Kleinman, M., Wang, X., Bennett, B. J., Gong, K. W., Navab, M., Harkema, J., Sioutas, C., Lusis, A. J., and Nel, A. E.: Ambient particulate pollutants in the ultrafine range promote early atherosclerosis and systemic oxidative stress, Circ. Res., 102(5), 589-596, 2008.

Araujo, J. A. and Nel, A. E.: Particulate matter and atherosclerosis: role of particle size, composition and oxidative stress, Particle and Fibre Toxicology, 6(24), doi:10.1186/1743-8977-6-24, 2009.

Arnold, F., Pirjola, L., Aufmhoff, H., Schuck, T., Lähde, T., and Hämeri, K.: First gaseous sulfuric acid measurements in automobile exhaust: Implications for volatile nanoparticle formation, Atmos. Environ., 40, 7097-7105, 2006.

Birch, M. E. and Cary, R. A.: Elemental carbon-based method for monitoring occupational exposure to particulate diesel exhaust, Aerosol Sci. Tech., 25, 221-241, 1996.

Bond, T. C. and Bergstrom, R. W.: Light absorption by carbonaceous particles: An investigative review, Aerosol Sci. Tech., 40(1), 27-67, doi:10.1080/02786820500421521, 2006.

Burtscher, H.: Physical characterization of particulate emissions from diesel engines: a review, Aerosol Sci. Tech., 36, 896-932, 2005.

Casati, R., Scheer, V., Vogt, R., and Benter, T.: Measurement of nucleation and soot mode particle emission from a diesel passenger car in real world and laboratory in situ dilution, Atmos. Environ., 41, 2125-2135, 2007.

Charron, A. and Harrison, R. M.: Primary particle formation from vehicle emissions during exhaust dilution in the roadside atmosphere, Atmos. Environ., 37, 4109-4119, 2003.

COST 633, Particulate Matter - Properties Related to Health Effects. COST 633. Final Report, available at: http://www2.dmu.dk/atmosphericenvironment/COST633/ Downloads/Final_report_part_2_May2009.pdf, May 2009.

De Filippo, A. and Maricq, M. M.: Diesel Nucleation Mode Particles: Semivolatile or Solid?, Environ. Sci. Technol., 42, 79577962, 2008.

De la Rosa, J. D., Sánchez de la Campa, A. M., Alastuey, A., Querol, X., González-Castanedo, Y., Fernández-Camacho, R., and Stein, A. F.: Using PM10 geochemical maps for defining the origin of atmospheric pollution in Andalusia (Southern Spain), Atmos. Environ., 44, 4595-4605, 2010.

$\mathrm{Du}, \mathrm{H}$. and Yu, F.: Nanoparticle formation in the exhaust of vehicles running on ultra-low sulfur fuel, Atmos. Chem. Phys., 8, 47294739, doi:10.5194/acp-8-4729-2008, 2008.

Dunn, M. J., Jiménez, J.-L., Baumgardner, D., Castro, T., McMurry, P. H., and Smith, J. N.: Measurements of Mexico City nanoparticle size distributions: Observations of new particle formation and growth, Geophys. Res. Lett., 31, L10102, doi:10.1029/2004GL019483, 2004.

EC WOrking group on particulate matter: REPORT - guidance to member states on $\mathrm{PM}_{10}$ monitoring and intercomparisons with the reference method, January 2002.

EU: 2008/50/EC Council Directive on ambient air quality and cleaner air for Europe, Official Journal L 152, 11 June 2008, 0001-0044, 2008.

Fernández-Camacho, R., de la Rosa, J., Sánchez de la Campa, A. M., González-Castanedo, Y., Alastuey, A., Querol, X., and 
Rodríguez, S.: Geochemical characterization of $\mathrm{Cu}$-smelter emission plumes with impact in an urban area of SW Spain, Atmos. Res., 96, 590-601, 2010.

Fruin, S. A., Winer, A. M., and Rodes, C. E.: Black carbon concentrations in California vehicles and estimation of in-vehicle diesel exhaust particulate matter exposures, Atmos. Environ., 38, 4123-4133, 2004.

Gidhagen, L., Johansson, C., Langner, J., and Foltescu, V. L.: Urban scale modelling of particle number concentration in Stockholm, Atmos. Environ., 39, 1711-1725, 2005.

Harrison, R. M. and Jones, A. M.: Multisite study of particle number concentrations in urban air, Environ. Sci. Technol., 39, 60636070, 2005.

Heikkilä, J., Virtanen, A., Rönkkö, T., Keskinen, J., Aakko-Saksa, P., and Murtonen, T.: Nanoparticle Emissions from a HeavyDuty Engine Running on Alternative Diesel Fuels, Environ. Sci. Technol., 43, 9501-9506, 2009.

Hermann, M., Wehner, B., Bischof, O., Han, H.-S., Krinke, T., Liu, W., Zerrath, A., and Wiedensohler, A.: Particle counting efficiencies of new TSI condensation particle counters, J. Aerosol Sci., 38, 674-682, 2007.

Hoffer, A., Gelencsér, A., Guyon, P., Kiss, G., Schmid, O., Frank, G. P., Artaxo, P., and Andreae, M. O.: Optical properties of humic-like substances (HULIS) in biomass-burning aerosols, Atmos. Chem. Phys., 6, 3563-3570, doi:10.5194/acp-6-3563-2006, 2006.

ICRP: Human respiratory tract model for radiological protection, Ann. ICRP 24(1-3), ICRP publication 66, 1994.

Kittelson, D. B.: Engines and nanoparticles: a review, J. Aerosol Sci., 29, 575-588, 1998.

Kulmala, M., Lehtinen, K. E. J., Laakso, L., Mordas, G., and Hämeri, K.: On the existence of neutral atmospheric clusters, Boreal Environ. Res., 10, 79-87, 2005.

Kulmala, M., Lehtinen, K. E. J., and Laaksonen, A.: Cluster activation theory as an explanation of the linear dependence between formation rate of $3 \mathrm{~nm}$ particles and sulphuric acid concentration, Atmos. Chem. Phys., 6, 787-793, doi:10.5194/acp-6-787-2006, 2006.

Kulmala, M. and Kerminen, V. M.: On the formation and growth of Atmospheric nanoparticles, Atmos. Res., 90, 132-150, 2008.

Mantilla, E.: Estudio de series temporales antiguas de parámetros meteorológicos y niveles de contaminantes atmosféricos, Contaminación por material particulado atmosférico en el entorno de la ría de Huelva, Junta de Andalucía, 73 pp., 2007 (in Spanish).

Mejía, J. F., Morawska, L., and Mengersen, K.: Spatial variation in particle number size distributions in a large metropolitan area, Atmos. Chem. Phys., 8, 1127-1138, doi:10.5194/acp-8-11272008, 2008.

Millán, M. M., Sanz, M. J., Salvador, R., and Mantilla, E.: Atmospheric dynamics and ozone cycles related to nitrogen deposition in the western Mediterranean, Environ. Pollut., 118, 167-186, 2002.

Morawska, L. and Zhang, J.: Combustion sources of particles. 1. Health relevance and source signatures, Chemosphere, 49, 10451058, 2002.

Morawska, L., Ristovski, Z., Jayaratne, E. R., Keogh, D. U., and Ling, X.: Review. Ambient nano and ultrafine particles from motor vehicle emissions: characteristics, ambient processing and implications on human exposure, Atmos. Environ., 42, 8113-
8138, 2008.

Oberdörster, G., Sharp, Z., Atudorei,V., Elder A., Gelein, R., Lunts, A., Kreyling, W., and Cox, C.: Extrapulmonary translocation of 650 ultrafine carbon particles following whole-body inhalation exposure of rats, J. Toxicol. Env. Heal. A, 65(20), 1531-1543, 2002.

Oberdörster, G., Sharp, Z., Atudorei, V., Elder, A., Gelein, R., Kreyling, W., and Cox, C.: Translocation of Inhaled Ultrafine Particles to the Brain, Inhal. Toxicol., 16, 1-9, 2004.

Pérez, N., Pey, J., Cusack, M., Cristina, R., Querol, X., Alastuey, A., and Viana, M.: Variability of particle number, black carbon and PM10, PM2.5 and PM1 levels and speciation: influence of road traffic emissions on urban air quality, Aerosol Sci. Tech., 44, 487-499, 2010.

Petzold, A. and Schönlinner, M.: Multi-angle absorption photometry - a new method for the measurement of aerosol light absorption and atmospheric black carbon, J. Aerosol Sci., 35, 421-441, 2004.

Pey, J., Querol, X., Alastuey, A., Rodríguez, S., Putaud, J. P., and Van Dingenen, R.: Source apportionment of urban fine and ultrafine particle number concentration in a Western Mediterranean city, Atmos. Environ., 43, 4407-4415, 2009.

Pirjola, L.: Effects of the increased UV radiation and biogenic VOC emissions on the ultrafine sulphate aerosol formation, J. Aerosol Sci., 30, 355-367, 1999.

Putaud, J.-P., Van Dingenen, R., Alastuey, A., Bauer, H., Birmili, W., Cyrys, J., Flentje, H., Fuzzi, S. Gehrig, R., Hansson, H. C., Harrison, R. M., Herrmann, H., Hitzenberger, R., Hüglin, C., Jones, A. M., Kasper-Giebl, A., Kiss, G., Kousa, A., Kuhlbusch, T. A. J., Löschau, G., Maenhaut, W., Molnar, A., Moreno, T., Pekkanen, J., Perrino, C., Pitz, M., Puxbaum, H., Querol, X., Rodriguez, S., Salma, I., Schwarz, J., Smolik, J., Schneider, J., Spindler, G., Ten Brink, H. , Tursic, J., Viana, M., Wiedensohler, A., and Raes, F.: A European aerosol phenomenology-3: Physical and chemical characteristics of particulate matter from 60 rural, urban, and kerbside sites across Europe, Atmos. Environ., 44, 1308-1320, 2010.

Puustinen, A., Hämeri, K., Pekkanen, J., Kulmala, M., De Hartog, J., Meliefste, K., Ten Brink, H., Kos, G., Katsouyanni, K., Karakatsani, A., Kotronarou, A., Kavouras, I., Meddings, C., Thomas, S., Harrison, R., Ayres, J. G., Van der Zee, S., and Hoek, G.: Spatial variation of particle number and mass over four European cities, Atmos. Environ., 41, 6622-6636, 2007.

Querol, X., Alastuey, A., de la Rosa, J. D., Sánchez de la Campa, A., Plana, F., and Ruiz, C. R.: Source apportionment analysis of atmospheric particulates in an industrialised urban site in southwestern Spain, Atmos. Environ., 36, 3113-3125, 2002.

Rodríguez, S., Querol, X., Alastuey, A., Viana, M. M., Alarcón, M., Mantilla, E., and Ruiz, C. R.: Comparative PM10-PM2.5 source contribution study at rural, urban and industrial sites during PM episodes in Eastern Spain, Sci. Total Environ., 328, 95113, 2004.

Rodríguez, S., Van Dingenen, R., Putaud, J.-P., Dell'Acqua, A., Pey, J., Querol, X., Alastuey, A., Chenery, S., Ho, K.-F., Harrison, R., Tardivo, R., Scarnato, B., and Gemelli, V.: A study on the relationship between mass concentrations, chemistry and number size distribution of urban fine aerosols in Milan, Barcelona and London, Atmos. Chem. Phys., 7, 2217-2232, doi:10.5194/acp-7-2217-2007, 2007. 
Rodríguez, S. and Cuevas, E.: The contributions of 'minimum primary emissions' and 'new particle formation enhancements' to the particle number concentration in urban air, J. Aerosol Sci., 38, 1207-1219, 2007.

Rodríguez, S., Cuevas, E., González, Y., Ramos, R., Romero, P. M., Pérez, N., Querol, X., and Alastuey, A.: Influence of sea breeze circulation and road traffic emissions on the relationship between particle number, black carbon, PM1, PM2.5 and PM2.5-10 concentrations in a coastal city, Atmos. Environ., 42, 6523-6534, 2008.

Rönkkö, T., Virtanenm A., Kannosto, J., Keskinen, J., Lappi, M., and Pirjola, L.: Nucleation Mode Particles with a Nonvolatile Core in the Exhaust of a Heavy Duty Diesel Vehicle, Environ. Sci. Technol., 41, 6384-6389, 2007.

Rose, D., Wehner, B., Ketzel, M., Engler, C., Voigtländer, J., Tuch, T., and Wiedensohler, A.: Atmospheric number size distributions of soot particles and estimation of emission factors, Atmos. Chem. Phys., 6, 1021-1031, doi:10.5194/acp-6-1021-2006, 2006.

Ruuskanen, J., Tuch, Th., Ten Brink, H., Peters, A., Khlystov, A., Mirme, A., Kos, G. P. A., Brunekreef, H. E., Wichmann, H. E., Buzorius, G., Vallius, M., Kreyling, W. G., and Pekkanen, J.: Concentrations of ultrafine, fine and $\mathrm{PM}_{2.5}$ particles in three $\mathrm{Eu}-$ ropean cities, Atmos. Environ., 35, 3729-3738, 2001.

Sánchez de la Campa, A.M., de la Rosa, J., Querol, X., Alastuey, A., and Mantilla, E.: Geochemistry and origin of PM10 in the Huelva region, Southwestern Spain, Environ. Res., 103, 305316, 2007.

Sánchez de la Campa, A. M., de la Rosa, J., Sánchez-Rodas, D., Oliveira, V., Alastuey, A., Querol, X., and Gómez Ariza, J. L.: Arsenic speciation study of PM2.5 in an urban area near a copper smelter, Atmos. Environ., 42, 6487-6495, 2008.

Sánchez de la Campa, A. M., Pio, C., de la Rosa, J. D., Querol, X., Alastuey, A., and González-Castanedo, Y.: Characterization and origin of EC and OC particulate matter near the Doñana National Park (SW Spain), Environ. Res., 109, 671-681, 2009.

Sánchez-Rodas, D., Sánchez de la Campa, A. M., de la Rosa, J. D., Oliveira, V., Gómez-Ariza, J. L., Querol, X., and Alastuey, A.: Arsenic speciation of atmospheric particulate matter (PM10) in an industrialised urban site in southwestern Spain, Chemosphere, 66, 1485-1493, 2007.
Second Position Paper on Particulate Matter, Report of CAFE Working Group on Particulate Matter, 20 December 2004 Clean Air For Europe, European Commission, 2004.

Shi, J. P., Khan, A. A., and Harrison, R. M.: Measurements of ultrafine particle concentration and size distribution in the urban atmosphere, Sci. Total Environ., 235, 51-64, 1999.

Sipilä, M., Berndt, T., Petäjä, T., Brus, D., Vanhanen, J., Stratmann, F., Patokoski, J., Mauldin, R. L., Hyvärinen, A. P., Lihavainen, H., and Kulmala, M.: The Role of Sulphuric Acid in Atmospheric Nucleation, Science, 327, 1234-1246, 2010.

Stanier, C. O., Khlystov, A. Y., and Pandis, S. N.: Ambient aerosol size distributions and number concentrations measured during the Pittsburgh Air Quality Study (PAQS), Atmos. Environ., 38, 3275-3284, 2004.

Van Dingenen, R., Raes, F., Putaud, J.-P., Baltensperger, U., Charron, A., Facchini, M.-C., Decesari, S., Fuzzi, S., Gehrig, R., Hansson, H.-C., Harrison, R. M., Hüglin, C., Jones, A. M., Laj, P., Lorbeer, G., Maenhaut, W., Palmgren, F., Querol, X., Rodriguez, S., Schneider, J., Ten Brink, H., Tunved, P., Torseth, K., Wehner, B., Weingartner, E., Wiedensohler, A., and Wåhlin, P.: A European aerosol phenomenology-1: physical characteristics of particulate matter at kerbside, urban, rural and background sites in Europe, Atmos. Environ., 38, 2561-2577, 2004.

Viana, M., Amato, F., Alastuey, A., Querol, X., Moreno, T., García Dos Santos, S., Herce, M. D., and Fernández Patier, R.: Chemical Tracers of Particulate Emissions from Commercial Shipping, Environ. Sci. Technol., 43, 7472-7477, 2009.

Wehner, B., Birmili, W., Gnauk, T., and Wiedensohler, A.: Particle number size distributions in a street canyon and their transformation into the urban-air background: measurements and a simple model study, Atmos. Environ., 36, 2215-2223, 2002.

Wehner, B. and Wiedensohler, A.: Long term measurements of submicrometer urban aerosols: statistical analysis for correlations with meteorological conditions and trace gases, Atmos. Chem. Phys., 3, 867-879, doi:10.5194/acp-3-867-2003, 2003.

Woo, K. S., Chen, D. R., Pui, D. Y. H., and McMurry, P. H.: Measurement of Atlanta aerosol size distributions: observation of ultrafine particle events, Aerosol Sci. Tech., 34, 75-87, 2001. 